\title{
The Evolution of Life Modes in Stictidaceae, with Three Novel Taxa
}

\author{
Vinodhini Thiyagaraja ${ }^{1,2,3}$, Robert Lücking ${ }^{4}{ }^{\circ}$, Damien Ertz ${ }^{5,6}{ }^{\circ}$, Samantha C. Karunarathna ${ }^{3,7}(\mathbb{0}$, \\ Dhanushka N. Wanasinghe $\left.{ }^{3,7}{ }^{(}\right)$, Saisamorn Lumyong ${ }^{8,9}$ and Kevin D. Hyde ${ }^{2,3,8,10, *}$
}

Citation: Thiyagaraja, V.; Lücking, R.; Ertz, D.; Karunarathna, S.C.; Wanasinghe, D.N.; Lumyong, S.; Hyde, K.D. The Evolution of Life Modes in Stictidaceae, with Three Novel Taxa. J. Fungi 2021, 7, 105. https://doi.org/10.3390/jof7020105

Academic Editor: Lei Cai

Received: 27 December 2020

Accepted: 28 January 2021

Published: 2 February 2021

Publisher's Note: MDPI stays neutral with regard to jurisdictional claims in published maps and institutional affiliations.

Copyright: (c) 2021 by the authors. Licensee MDPI, Basel, Switzerland. This article is an open access article distributed under the terms and conditions of the Creative Commons Attribution (CC BY) license (https:// creativecommons.org/licenses/by/ $4.0 /)$.
1 Department of Entomology and Plant Pathology, Faculty of Agriculture, Chiang Mai University, Chiang Mai 50200, Thailand; vino.thiyagaraja@gmail.com

2 Centre of Excellence in Fungal Research, Mae Fah Luang University, Chiang Rai 57100, Thailand

3 CAS Key Laboratory for Plant Biodiversity and Biogeography of East Asia (KLPB), Kunming Institute of Botany, Chinese Academy of Science, Kunming 650201, China; samanthakarunarathna@gmail.com (S.C.K.); dnadeeshan@gmail.com (D.N.W.)

4 Botanischer Garten und Botanisches Museum, Freie Universität Berlin, Königin-Luise-Str. 6-8, 14195 Berlin, Germany; R.Luecking@bgbm.org

5 Research Department, Meise Botanic Garden, Nieuwelaan 38, BE-1860 Meise, Belgium; damien.ertz@jardinbotaniquemeise.be

6 Fédération Wallonie-Bruxelles, Service Général de l'Enseignement Supérieur et de la Recherche Scientifique, Rue A. Lavallée 1, BE-1080 Bruxelles, Belgium

7 World Agro forestry Centre East and Central Asia, Kunming 650201, China

8 Department of Biology, Faculty of Science, Chiang Mai University, Chiang Mai 50200, Thailand; scboi009@gmail.com

9 Center of Excellence in Bioresources for Agriculture, Industry and Medicine, Faculty of Science, Chiang Mai University, Chiang Mai 50200, Thailand

10 Innovative Institute of Plant Health, Zhongkai University of Agriculture and Engineering, Haizhu District, Guangzhou 510225, China

* Correspondence: kdhyde3@gmail.com

Abstract: Ostropales sensu lato is a large group comprising both lichenized and non-lichenized fungi, with several lineages expressing optional lichenization where individuals of the same fungal species exhibit either saprotrophic or lichenized lifestyles depending on the substrate (bark or wood). Greatly variable phenotypic characteristics and large-scale phylogenies have led to frequent changes in the taxonomic circumscription of this order. Ostropales sensu lato is currently split into Graphidales, Gyalectales, Odontotrematales, Ostropales sensu stricto, and Thelenellales. Ostropales sensu stricto is now confined to the family Stictidaceae, which includes a large number of species that are poorly known, since they usually have small fruiting bodies that are rarely collected, and thus, their taxonomy remains partly unresolved. Here, we introduce a new genus Ostropomyces to accommodate a novel lineage related to Ostropa, which is composed of two new species, as well as a new species of Sphaeropezia, S. shangrilaensis. Maximum likelihood and Bayesian inference analyses of mitochondrial small subunit spacers (mtSSU), large subunit nuclear rDNA (LSU), and internal transcribed spacers (ITS) sequence data, together with phenotypic data documented by detailed morphological and anatomical analyses, support the taxonomic affinity of the new taxa in Stictidaceae. Ancestral character state analysis did not resolve the ancestral nutritional status of Stictidaceae with confidence using Bayes traits, but a saprotrophic ancestor was indicated as most likely in a Bayesian binary Markov Chain Monte Carlo sampling (MCMC) approach. Frequent switching in nutritional modes between lineages suggests that lifestyle transition played an important role in the evolution of this family.

Keywords: 3 new taxa; ancestral character state analysis; asexual morph; Lecanoromycetes; Ostropomyces; sexual morph; Sphaeropezia 


\section{Introduction}

Lichenization is a successful lifestyle, forming a stable symbiotic association between fungi with cyanobacteria and/or algae. About 13\% of the known fungal species form lichens, and these dominate around 7\% of the earth's terrestrial surface [1-3]. The origin of lichenization remains controversial. Molecular studies show that lichenization and de-lichenization events occurred independently in different lineages of Ascomycota and Basidiomycota [1,3-12].

Lecanoromycetes is the largest lichenized lineage in Ascomycota, comprising more than 15,000 species [1,13-15]. It currently contains four subclasses: Acarosporomycetidae, Lecanoromycetidae, Ostropomycetidae, and Umbilicariomycetidae $[1,16]$. Within subclass Ostropomycetidae, Ostropales sensu lato exhibits a remarkable transition toward larger, non-lichenized, saprotrophic or biotrophic lineages, including a loss of lichenization within Stictidaceae, making this group the most striking example comprising secondarily delichenized lineages in Lecanoromycetes $[1,3,13,17,18]$.

Ostropales was introduced by Nannfeldt in 1932 to encompass a single family Ostropaceae, which is a younger synonym of Stictidaceae [19]. Various molecular studies have been conducted to resolve the phylogenetic relationships within Ostropales [18-28]. The delimitation of Ostropales has changed over time due to a high level of morphological plasticity $[18,19]$, and the taxonomy of various groups remains unresolved [29]. Ostropales was recently very broadly defined [1] and reduced to a single family, Stictidaceae, whereas related families are now recognized in the separate orders Graphidales, Gyalectales, Odontotrematales, and Thelenellales $[13,30]$. Stictidaceae includes mostly small, drought-tolerant fungi [31], which have been poorly studied, and their generic delimitation is yet to be resolved $[19,31,32]$. There are many opportunities for discovering new species, even in well-studied areas [19].

Species of Stictidaceae are mainly saprotrophic and partly lichenized or lichenicolous, and they inhabit mostly bark and rock substrata [32]. Some species show optional lichenization; i.e., the same fungus may be either lichenized when growing on bark or saprotrophic when developing on wood [32]. Many species of Stictidaceae are characterized by ascomata with crystalline excipular incrustations and by long, filiform ascospores [24]. Sherwood [33] provided a detailed monograph of this family with special emphasis on taxa recorded from the USA.

Here, we provide updated multi-gene phylogenetic analyses for Ostropales and related orders focusing on Stictidaceae, thereby describing a newly discovered genus and three new species. Detailed morphological descriptions are provided for the new taxa. In addition, ancestral character state analysis was performed to assess the origin and transition of the various lifestyles occurring in the family.

\section{Materials and Methods}

\subsection{Phenotypic Analysis}

The bark and stem plant materials of newly described taxa were collected from China and Thailand and brought to the laboratory in paper bags. Materials were examined using a Motic SMZ 168 Series microscope. Hand sections of the ascomata were mounted with water, $5 \% \mathrm{KOH}$ and $\mathrm{KI}(5 \% \mathrm{KOH}$ and Lugol's solution), and examined. Sections of ascomata and other micro-morphological characteristics were photographed using a Nikon ECLIPSE 80i compound microscope fitted with a Canon 550D digital camera. All microscopic measurements refer to dimensions in water and were made with Tarosoft Image Frame Work (0.9.0.7), and images used for figures were processed with Adobe Photoshop CS6 Extended 10.0 software (Adobe Systems, San Jose, CA, USA). The specimens were deposited in the Mae Fah Luang University (MFLU) Herbarium, Chiang Rai, Thailand. Index Fungorum and Faces of Fungi were registered following Index Fungorum [34] and Jayasiri et al. [35]. 


\subsection{DNA Extraction, PCR Amplification, and Gene Sequencing}

Genomic DNA was extracted directly from the ascomatal tissue and thalli of fungi as outlined by Wanasinghe et al. [36]. An E.Z.N.A. ${ }^{\circledR}$ Forensic DAT (D3591-01, Omega Bio-Tek) DNA extraction kit was used to extract DNA by following the manufacturer's instructions. DNA samples that were intended for use as a template for PCR were stored at $4{ }^{\circ} \mathrm{C}$ for use in regular work, and duplicates were stored at $-20^{\circ} \mathrm{C}$ for long-term storage. The mitochondrial small subunit spacers (12S, mtSSU), large subunit nuclear rDNA (28S, LSU) and internal transcribed spacers (ITS) were amplified with primer pairs mtSSU1 and mtSSU3R [37], LR0R and LR5 [38], and ITS5 and ITS4 [39]. The PCR amplification for each gene was performed using a final volume of $25 \mu \mathrm{L}$, which was comprised of $2.0 \mu \mathrm{L}$ of DNA template, $1 \mu \mathrm{L}$ of each forward and reverse primers, $12.5 \mu \mathrm{L}$ of Taq PCR Super Mix (mixture of Easy Taq TM DNA Polymerase, dNTPs, obtained buffer (Beijing Trans Gen Biotech Co., Chaoyang District, Beijing, China)) and $8.5 \mu \mathrm{L}$ of sterilized water.

The PCR amplifications were performed following Zoller et al. [37], Vilgalys and Hester [38], and White et al. [39] for the genes mtSSU, LSU, and ITS respectively. Finally, PCR products were examined on $1 \%$ agarose electrophoresis gels and stained with ethidium bromide. Purification and DNA sequencing were performed at Shanghai Sangon Biological Engineering Technology \& Services Co. (Shanghai, China). The nucleotide sequence data acquired were deposited in GenBank. Alignments and phylogenetic trees were submitted to TreeBASE under submission number 27653.

\subsection{Phylogenetic Analyses and Species Recognition}

The Basic Local Alignment Search Tool (BLAST) search engine of the National Center for Biotechnology Information (NCBI) was used for the preliminary identification of DNA sequences of the new taxa [40]. Sequences of available closely related taxa for Ostropales were retrieved from GenBank (Table 1), including all representatives available of Stictidaceae. Phylogenetic analyses were constructed based on mtSSU, LSU, and ITS sequence data. Outgroup taxa were selected following Lücking [30]. The final combined alignment of Stictidaceae comprised 2530 nucleotide positions and resulted in 107 taxa. We also conducted a multi-marker phylogenetic analysis of Ostropomycetidae to check the placement of Ostropales sensu stricto following Kraichak et al. [13] and Lücking [30] for 167 taxa based on $\mathrm{mtSSU}, \mathrm{LSU}$, and ITS sequence data.

Table 1. Taxa used in this study for the analyses of combined mitochondrial small subunit spacers (mtSSU), large subunit nuclear rDNA (LSU), and internal transcribed spacers (ITS) sequence data and their GenBank accession numbers. The newly generated sequences are indicated in boldface.

\begin{tabular}{|c|c|c|c|c|}
\hline \multirow[b]{2}{*}{ Species } & \multirow[b]{2}{*}{ Strains } & \multicolumn{3}{|c|}{ GenBank Accession Numbers } \\
\hline & & mtSSU & LSU & ITS \\
\hline Absconditella sphagnorum 1 & T. Laukka 52 (TUR) & EU940247 & EU940095 & - \\
\hline Absconditella sphagnorum 2 & 17 Feb 02 Palice (HB Palice) & AY300872 & AY300824 & - \\
\hline Acarosporina microspora & AFTOL-ID 78 & AY584612 & AY584643 & DQ782834 \\
\hline Carestiella socia 1 & GG2410 & AY661677 & AY661687 & AY661687 \\
\hline Carestiella socia 2 & GG2437a & AY661678 & AY661682 & AY661682 \\
\hline Cryptodiscus cladoniicola 1 & RP160 & KY661675 & KY661653 & KY661620 \\
\hline Cryptodiscus cladoniicola 2 & RP159 & KY661674 & KY661652 & KY661619 \\
\hline Cryptodiscus epicladonia & RP208 & KY661680 & - & KY661628 \\
\hline Cryptodiscus foveolaris 1 & EB155 & FJ904695 & - & FJ904673 \\
\hline Cryptodiscus foveolaris 2 & EB86 & FJ904692 & - & FJ904670 \\
\hline Cryptodiscus foveolaris 3 & EB147 & FJ904694 & - & FJ904672 \\
\hline Cryptodiscus galaninae & RP314 & - & - & KY661636 \\
\hline Cryptodiscus gloeocapsa & EB93 & FJ904696 & - & FJ904674 \\
\hline Cryptodiscus incolor & EB164 & FJ904697 & - & FJ904675 \\
\hline Cryptodiscus muriformis 1 & UPS F-647154 & MG281972 & MG281962 & MG281962 \\
\hline
\end{tabular}


Table 1. Cont.

\begin{tabular}{|c|c|c|c|c|}
\hline \multirow[b]{2}{*}{ Species } & \multirow[b]{2}{*}{ Strains } & \multicolumn{3}{|c|}{ GenBank Accession Numbers } \\
\hline & & mtSSU & LSU & ITS \\
\hline Cryptodiscus muriformis 2 & H.B. 6773 & MG281973 & MG281963 & MG281963 \\
\hline Cryptodiscus pallidus 1 & EB60 & FJ904700 & FJ904678 & FJ904678 \\
\hline Cryptodiscus pallidus 2 & EB173 & FJ904702 & FJ904680 & FJ904680 \\
\hline Cryptodiscus pini 1 & EB82 & FJ904704 & FJ904682 & FJ904682 \\
\hline Cryptodiscus pini 2 & EB178 & FJ904705 & FJ904683 & FJ904683 \\
\hline Cryptodiscus pini 3 & EB181 & FJ904706 & FJ904684 & FJ904684 \\
\hline Cryptodiscus tabularum 1 & CO205 & FJ904712 & FJ904690 & FJ904690 \\
\hline Cryptodiscus tabularum 2 & EB169 & FJ904711 & FJ904689 & FJ904689 \\
\hline Cryptodiscus tabularum 3 & EB77 & FJ904709 & FJ904687 & FJ904687 \\
\hline Cyanodermella asteris & 03HOR06-2-4 & - & KT758843 & KT758843 \\
\hline Cyanodermella banksiae & CPC:32105 & - & NG_064548 & NR_159835 \\
\hline Cyanodermella oleoligni & DTO 301-G1 & KX999144 & KX950461 & KX950434 \\
\hline Cyanodermella viridula & EB146 & - & MG281964 & MG281964 \\
\hline Diploschistes scruposus & SFB 95 & KC167052 & - & KC167001 \\
\hline Eriospora leucostoma 1 & СРC:35594 & - & MT223890 & MT223795 \\
\hline Eriospora leucostoma 2 & CPC:35598 & - & MT223891 & MT223796 \\
\hline Fitzroyomyces cyperacearum 1 & CPC:32209 & - & NG_058513 & NR_156387 \\
\hline Fitzroyomyces cyperacearum 2 & MFLU 18-0695b & - & MK4999361 & 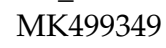 \\
\hline Fitzroyomyces cyperacearum 3 & MFLU 18-0695a & - & MK499363 & - \\
\hline Geisleria sychnogonoides 1 & Caceres \& Aptroot 13560 (ABL) & КС689751 & KC689752 & - \\
\hline Geisleria sychnogonoides 2 & GESY7510 & KF220306 & KF220304 & - \\
\hline Geisleria sychnogonoides 3 & GESY7509 & KF220305 & - & - \\
\hline Glomerobolus gelineus 1 & AFTOL-ID 1349 & DQ247784 & DQ247803 & DQ247782 \\
\hline Glomerobolus gelineus 2 & JK 5584C & DQ247783 & DQ247798 & - \\
\hline Hormodochis aggregata 1 & CBS:145904 & - & - & NR_166307 \\
\hline Hormodochis aggregate 2 & CPC:37499 & - & MN317288 & MN313807 \\
\hline Hormodochis aggregata 3 & CPC:35475 & - & MN317287 & MN313806 \\
\hline Ingvariella bispora 1 & DUKE 1444446 & HQ659175 & - & - \\
\hline Ingvariella bispora 2 & MALich 15288 & HQ659173 & HQ659184 & - \\
\hline Ingvariella bispora 3 & BCNLich 17183 & HQ659174 & HQ659185 & - \\
\hline Myriotrema olivaceum & Kalb 39107 & KJ435181 & KJ435111 & - \\
\hline Neofitzroyomyces nerii & CBS:145088 & - & MK047504 & MK047454 \\
\hline Neostictis nigricans & MFLU 18-1380 & - & MT214610 & МT310654 \\
\hline Ostropa barbara 1 & S F302817 & MG281974 & MG281965 & MG281965 \\
\hline Ostropa barbara 2 & EB85 & HM244752 & HM244773 & HM244773 \\
\hline Ostropa barbara 3 & G. M. 2015-04-28.1 & - & KY608095 & KY608095 \\
\hline Ostropomyces pruinosellus & MFLU 20-0538 & MW400963 & MW400966 & MW400964 \\
\hline Ostropomyces thailandicus & MFLU 20-0539 & - & MW397060 & MW400967 \\
\hline Phacidiella eucalypti & CBS 120255 & - & MT373344 & MT373361 \\
\hline Phacidiella podocarpi & CBS 138904 & - & NG_058118 & NR_137934 \\
\hline Phaeographis spondaica & Lumbsch 19633 & JX421280 & - & - \\
\hline Porina nucula & Lücking 17007-c & KJ449310 & - & - \\
\hline Robergea cubicularis 1 & G.M. 2013-05-09.1 & - & KY611899 & KY611899 \\
\hline Robergea cubicularis 2 & G.M. 2017-10-12.1 & - & MN833317 & MN833317 \\
\hline Schizoxylon albescens 1 & GG236 & AY661680 & AY661689 & AY661689 \\
\hline Schizoxylon albescens 2 & GG2696a & DQ401142 & DQ401144 & DQ401144 \\
\hline Schizoxylon albescens 3 & Wedin $8365(\mathrm{~S})$ & - & - & HQ287353 \\
\hline Schizoxylon albescens 4 & Wedin $8364(S)$ & - & - & HQ287352 \\
\hline Schizoxylon albescens 5 & Wedin 8356 b (S) & - & - & HQ287350 \\
\hline Schizoxylon albescens 6 & Wedin 8359 (S) & - & - & HQ287351 \\
\hline Schizoxylon albescens 7 & Wedin 8327 (S) & - & - & HQ287349 \\
\hline Schizoxylon albescens 8 & Wedin $8324(\mathrm{~S})$ & - & - & HQ287348 \\
\hline Schizoxylon albescens 9 & Wedin 8254 (S) & - & - & HQ287347 \\
\hline Schizoxylon berkeleyanum & F209682 & MG281975 & MG281966 & MG281966 \\
\hline Schizoxylon gilenstamii 1 & MW9490 & MG281977 & MG281968 & MG281968 \\
\hline
\end{tabular}


Table 1. Cont.

\begin{tabular}{|c|c|c|c|c|}
\hline \multirow[b]{2}{*}{ Species } & \multirow[b]{2}{*}{ Strains } & \multicolumn{3}{|c|}{ GenBank Accession Numbers } \\
\hline & & mtSSU & LSU & ITS \\
\hline Schizoxylon gilenstamii 2 & MW9496 & MG281978 & MG281969 & MG281969 \\
\hline Sphaeropezia arctoalpina & Baloch SW057 & HM244736 & HM244760 & - \\
\hline Sphaeropezia capreae 1 & GG2560 & AY661674 & AY661684 & - \\
\hline Sphaeropezia capreae 2 & UPS (Gilenstam 2633a) & HM244751 & HM244772 & - \\
\hline Sphaeropezia cassiopes & Baloch s.n. (S) & HM244746 & - & - \\
\hline Sphaeropezia diffindens & Baloch SW020 (S) & HM244747 & - & - \\
\hline Sphaeropezia leucocheila & PDD 98299 & MK547101 & MK547099 & MK547090 \\
\hline Sphaeropezia lyckselensis 1 & Gilenstam 2651 (S) & JX266156 & JX266158 & - \\
\hline Sphaeropezia lyckselensis 2 & Gilenstam 2659 & HM244750 & HM244771 & - \\
\hline Sphaeropezia mycoblasti & Wedin 8509 \& Westberg (S) & JX266157 & JX266159 & - \\
\hline Sphaeropezia ochrolechiae & Wedin 6729 (UPS) & - & JX266160 & - \\
\hline Sphaeropezia shangrilaensis & MFLU 20-0537 & MW400962 & MW400965 & MW400955 \\
\hline Stictis brunnescens 1 & EB84 & MG281979 & - & - \\
\hline Stictis brunnescens 2 & Gilenstam 2359 (UPS) & AY661679 & - & AY661688 \\
\hline Stictis brunnescens 3 & SFB1100 & MG281981 & - & MG281970 \\
\hline Stictis brunnescens 4 & MW8571 & MG281980 & - & - \\
\hline Stictis brunnescens 5 & SFB1105 & MG281982 & - & MG281971 \\
\hline Stictis confusa 1 & Wedin 7070 (UPS) & DQ401141 & - & DQ401143 \\
\hline Stictis confusa 2 & AN3222 & AY527365 & - & AY527336 \\
\hline Stictis mollis 1 & GG2440b & AY527342 & - & AY527313 \\
\hline Stictis mollis 2 & GG2445a & AY527347 & - & AY527318 \\
\hline Stictis mollis 3 & GG2370 & AY527339 & - & AY527310 \\
\hline Stictis mollis 4 & GG2458b & AY527345 & - & AY527316 \\
\hline Stictis populorum 1 & GG2618 & AY527360 & - & AY527331 \\
\hline Stictis populorum 2 & GG2610a & AY527356 & - & AY527327 \\
\hline Stictis populorum 3 & MW7301 & AY527363 & - & AY527334 \\
\hline Stictis radiata 1 & MW6493 & AY527338 & - & AY527309 \\
\hline Stictis radiata 2 & GG2449a & AY340532 & - & AY527308 \\
\hline Stictis radiata 3 & AFTOL-ID 398 & AY584727 & - & DQ782846 \\
\hline Stictis urceolata 1 & MFLU 19-2695 & - & MN989186 & - \\
\hline Stictis urceolata 2 & LT21500 & AY661676 & AY661686 & AY661686 \\
\hline Stictis urceolata 3 & AFTOL-ID 96 & - & - & HQ650601 \\
\hline Trichothelium epiphyllum & Baloch CR-127 & AY648901 & - & - \\
\hline Trinathotrema stictideum 1 & F:Luecking 17541b & GU380288 & - & - \\
\hline Trinathotrema stictideum 2 & F:Luecking 28093 & GU380287 & - & - \\
\hline Wirthiotrema glaucopallens & DNA1336 & JF828972 & - & - \\
\hline Xyloschistes platytropa & H:Bjork 05-242 & KJ766517 & KJ766680 & - \\
\hline
\end{tabular}

Phylogenetic analyses of both individual and combined aligned data were performed under Maximum Likelihood (ML) and Bayesian criteria. The multiple alignments of all consensus sequences, as well as the reference sequences were automatically generated with MAFFT v. 7 [41]. Terminal ends of sequences and ambiguous regions were trimmed manually using BioEdit v. 7.0.5.2 [42] and excluded from the dataset. The phylogenetic web tool "ALTER" [43] was used to convert sequence alignment from FASTA to PHYLIP for RAxML analysis and from FASTA to NEXUS format for Bayesian analysis. The estimated model of ML and Bayesian analyses were performed independently for each locus using MrModeltest v.2.2 [44]. ML was generated using the RAxML-HPC2 on XSEDE (8.2.8) in the CIPRES Science Gateway platform [45] with 1000 separate runs using the GTR $+\mathrm{I}+\mathrm{G}$ model of evolution. MrBayes v. 3.1.2 was used to perform Bayesian analysis [46]. MCMC was run for 50,000,000 generations, and trees were sampled every 100th generation. The first $10 \%$ of trees that represented the burn-in phase were discarded, and only the remaining $90 \%$ of trees were used for calculating posterior probabilities (PP) for the majority rule consensus tree. The resulting trees were drawn in FigTree v1.4.0 [47]; then, they were copied to Microsoft PowerPoint 2013 and converted to jpeg files using Adobe Photoshop CS6 Extended 10.0 (Adobe Systems, San Jose, CA, USA). 


\subsection{Ancestral Character State Analyses}

We employed ancestral character reconstruction to study the evolutionary history of selected characters [48], specifically lifestyle changes among Ostropales sensu lato and possible gains and losses of lichenization. The following lifestyle states were used: lichenized with chlorococcoid algae, lichenized with trentepohlioid algae, non-lichenized saprotrophic and lichenicolous. RASP 3.2.1 (Reconstruct Ancestral State in Phylogenies) was used to conduct ancestral character analysis, using the two approaches, Bayes Traits and Bayesian Binary MCMC $[49,50]$. Both approaches were performed and visualized using default settings as follows: 1,010,000 iterations for BayesTraits with a burn-in of 10,000, sampling 1000 trees and with 10 ML trees; 50,000 generations for Bayesian Binary MCMC, with 10 chains, a sample frequency of 100 , a temperature of 0.1 , state frequencies fixed (JC), and among-site rate variation equal.

\section{Results}

\subsection{Phylogenetic Analyses}

Ostropales sensu lato were well recovered including Graphidales, Gyalectales, Ostropales sensu stricto (=Stictidaceae), and Thelenellales (Figure 1). No conflict was detected by comparing the significantly supported relationships of the individual topologies of the three markers (mtSSU, LSU, and ITS) that were subsequently concatenated (Supplementary Figures S1-S6). In a second step, we improved the terminal resolution in Stictidaceae by using only closely related lineages as an outgroup (Figure 2). Thereby, Stictidaceae included the following sequenced genera: Absconditella, Carestiella, Cryptodiscus, Cyanodermella, Eriospora, Fitzroyomyces, Geisleria, Glomerobolus, Hormodochis, Ingvariella, Nanostictis, Neostictis, Neofitzroyomyces, Ostropa, the new genus Ostropomyces, Phacidiella, Robergea, Schizoxylon, Sphaeropezia, Stictis, Trinathotrema, and Xyloschistes. All genera were resolved as monophyletic except Stictis (Figure 2).

The best scoring RAxML tree was selected to represent the relationships among the taxa, with the final ML optimization likelihood value of -29077.976127 (Figure 2). The parameters for the GTR $+\mathrm{I}+\mathrm{G}$ model of combined $\mathrm{mtSSU}$, LSU, and ITS were as follows: estimated base frequencies $\mathrm{A}=0.287442, \mathrm{C}=0.205916, \mathrm{G}=0.252694, \mathrm{~T}=0.253948$, substitution rates $\mathrm{AC}=1.393327, \mathrm{AG}=2.735680, \mathrm{AT}=2.386601, \mathrm{CG}=0.840662, \mathrm{CT}=5.674536$ and $\mathrm{GT}=1.000000$. The ML and Bayesian analyses both resulted in trees with similar topologies. Bayesian posterior probabilities from MCMC were evaluated with a final average standard deviation of split frequencies $=0.005790$.

\subsection{Ancestral Character State Analysis}

The recently introduced genera, such as Eriospora, Fitzroyomyces, Neofitzroyomyces, Neostictis, and Phacidiella, show saprotrophic lifestyle (Figure 3). Stictis was recovered as polyphyletic, with taxa expressing a lichenized or saprotrophic lifestyle or optional lichenization. Most species of Stictis show a saprotrophic lifestyle, including the type species of the genus, Stictis radiata. Stictis urceolata, as well as the lineage formed by S. populorum and S. confusa, are lichenized with chlorococcoid green algae. Stictis mollis is optionally lichenized, with specimens being either saprotrophic (GG2445a, GG2458b) or lichenized (GG2370, GG2440b). Species of Schizoxylon also show either a saprotrophic lifestyle or optional lichenization: a lichenized specimen of S. albescens (GG2696a) was isolated from the bark of Populus tremula, while a saprotrophic specimen (GG236) was isolated from dead twigs and branches of Populus tremula. Lichenized and facultatively lichenized Stictidaceae are generally associated with chlorococcoid green algae, except for Trinathotrema stictideum, which associates with a trentepohlioid photobiont (Figure 3). The genera Absconditella and Geisleria form a lichenized lineage, while the lichenized Ingvariella is part of a distinct lineage close to the saprotrophic Xyloschistes platytropa. Lichenicolous species are nested with saprotrophic species in the genera Cryptodiscus and Sphaeropezia. Three different lifestyles (lichenized, saprotrophic, and lichenicolous) are present within the genus Cryptodiscus. 


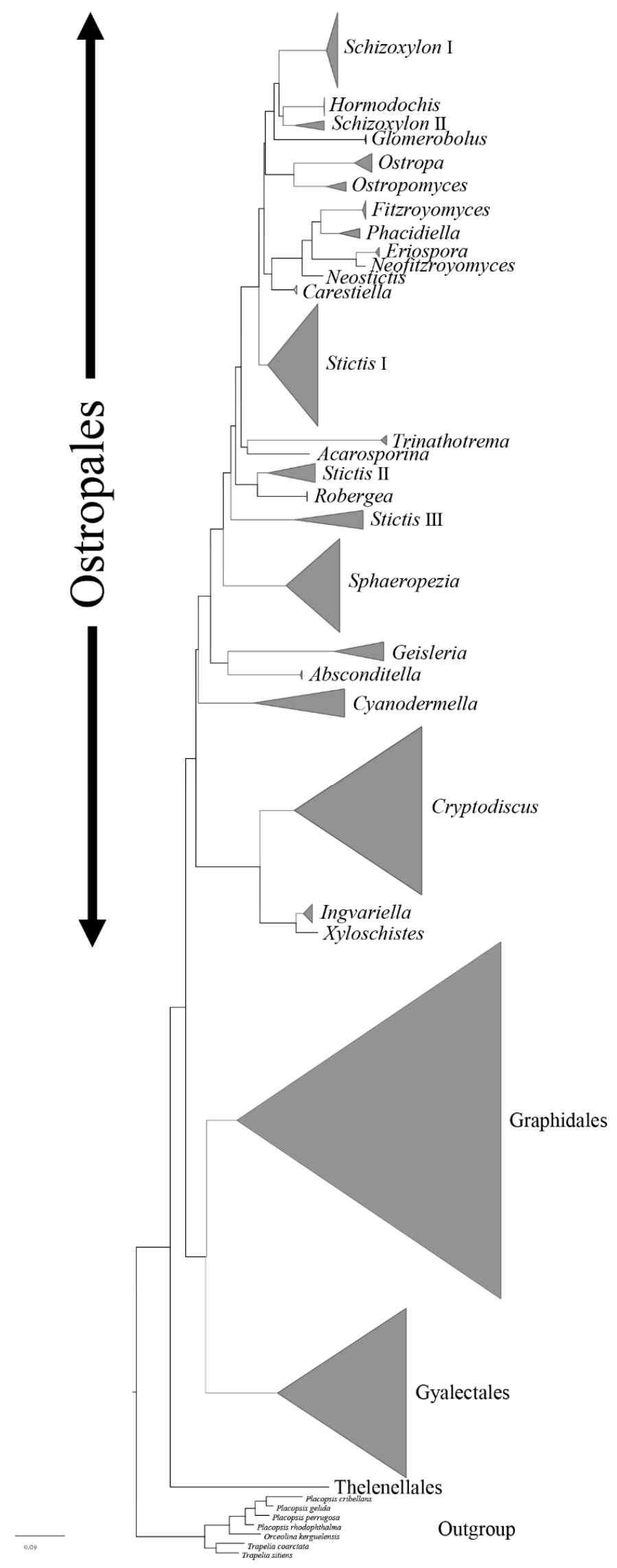

Figure 1. Cartoon tree of major clades for Ostropales sensu lato of combined mtSSU, LSU, and ITS partial sequence data based on RAxML tree analysis. 


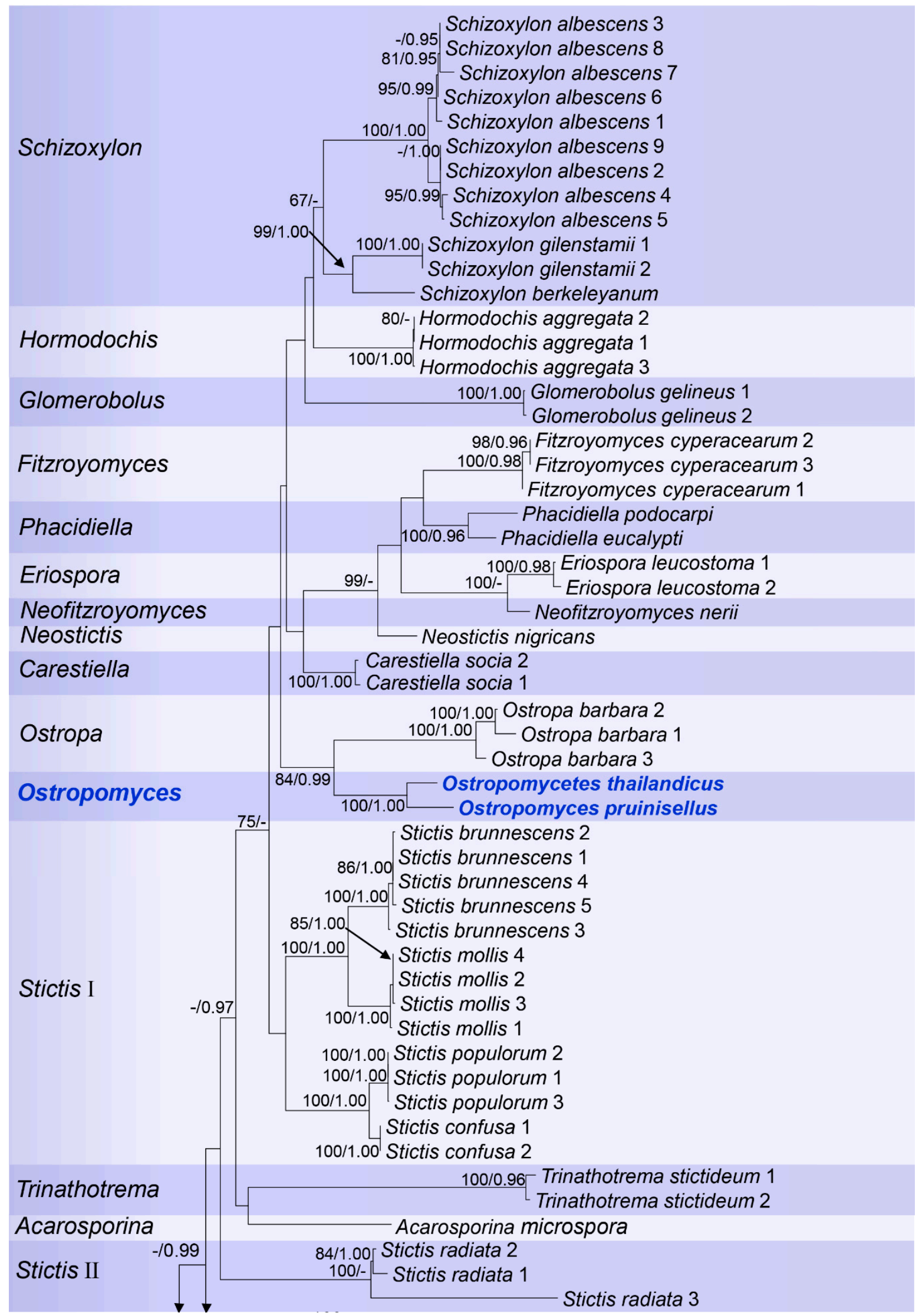

Figure 2. Cont. 


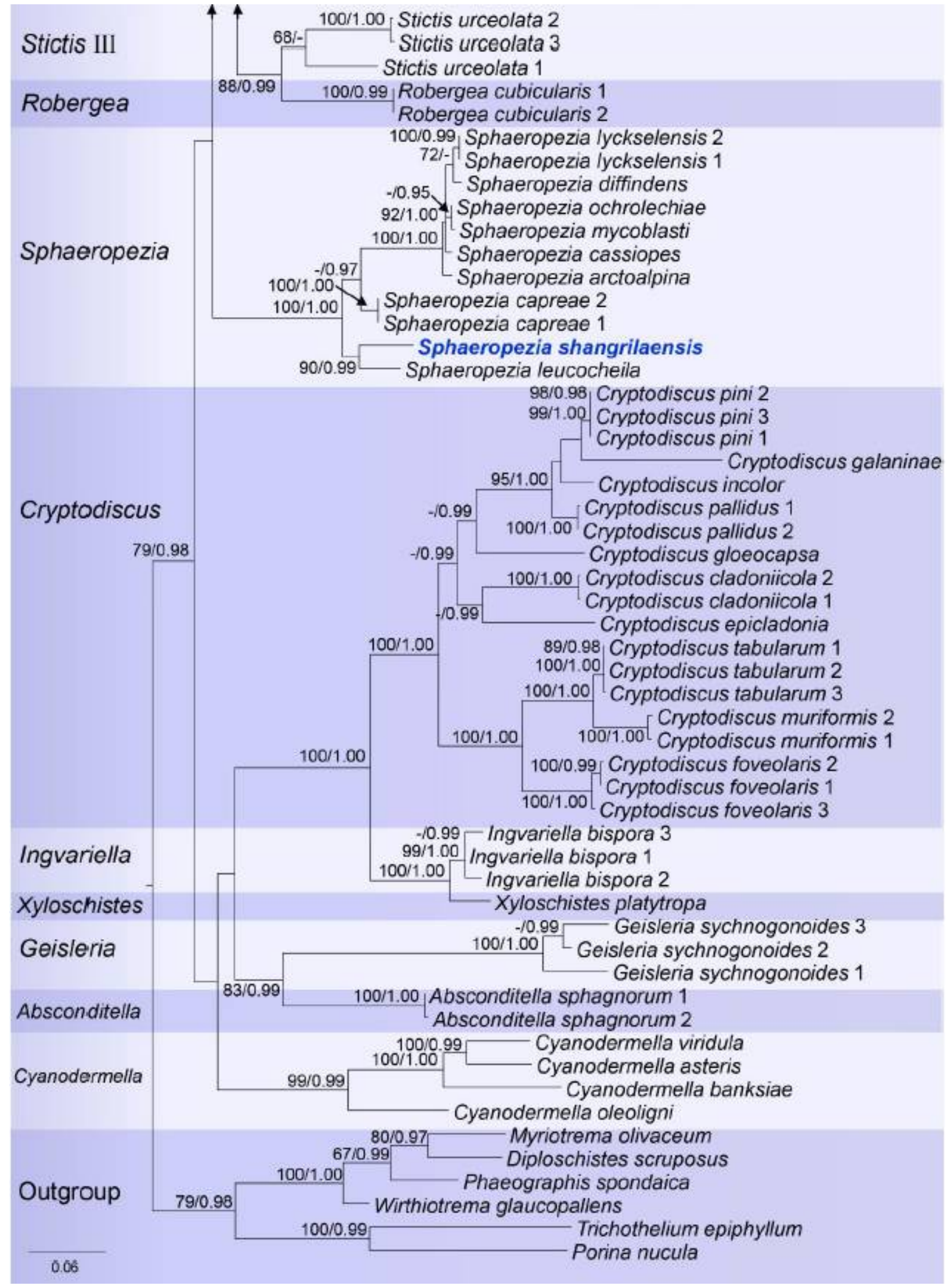

Figure 2. RAxML tree based on analysis of combined mtSSU, LSU, and ITS partial sequence data for Stictidaceae. Bootstrap support values for Maximum Likelihood (ML) equal to or greater than 65\%, and Bayesian posterior probabilities (BP) equal to or greater than 0.90 are given as ML/BP above the nodes. The new species and the genus found in this study are displayed in blue bold. 
- Non-lichenized (saprotrophic)

- Lichenized (chlorococcoid)

- Lichenized (trentepohlioid)

- Lichenicolous

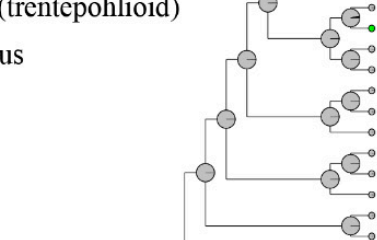
Schizoxylon albescens 3
Schizoxylon albescens 8 Schizoxylon albescens 7 Schizoxylon albescens 6 Schizoxylon albescens 1
Schizoxylon albescens 9 Schizoxylon albescens 9

Schizoxylon albescens 2 Schizoxylon albescens 4 Schizoxylon gilenstamii 1 Schizoxylon gilenstamii 2 Schizoxylon berkeleyanum Hormodochis aggregata 2 Hormodochis aggregata Hormodochis aggregata 3 Glomerobolus gelineus 1
Glomerobolus gelineus 2 ${ }_{-}^{\circ}$ Fitzroyomyces cyperacearum $2^{\circ}$

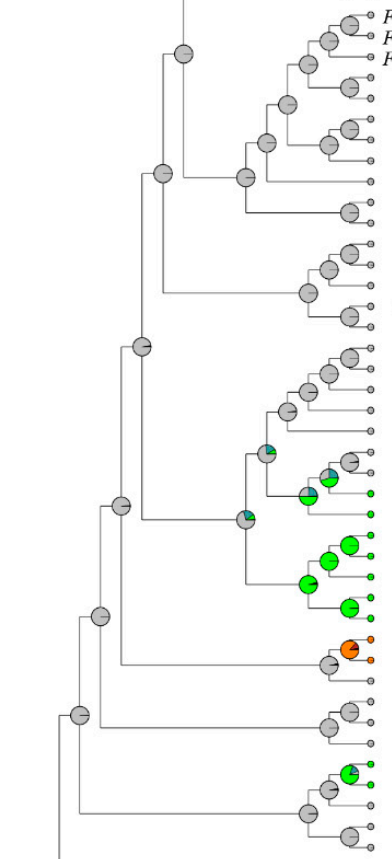

Phacidiella podocarpi
Phoces Phacidiella eucalypti Eriosporaleucostoma 1 Eriosporaleucostoma 2 Neofitzroyomyces neri Neostictis nigricans Carestiella socia 2 Carestiella socia 1
Ostropa barbara 2 Ostropa barbara 2
Ostropa barbara 1 Ostropa barbara 3 Ostropomycostes thrilandicis Stictis brunnescens Stictis brunnescens 1 Stictis brunnescens 4 Stictis brunnescens 5 Stictis brunnescens
Stictis mollis 4 Stictis mollis 4
Stictis mollis 2
Stictis mollis 3 Stictis mollis 3 Stictis populorum Stictis populorum 2
Stictis populorum 1 Stictis populorum 3 Stictis confusa Stictis confusa

Trinathotrema stictideum Trinathotrema stictideum 2 carosporina microspora
Stictis radiata 2 Stictis radiata Stictis radiata 3 Stictis urceolata Stictis urceolata 1 Robergea cubicularis 1
Robergea cubicularis 2 Sphaeropezia lyckselensis 2
Sphaeropezia lyckselensis

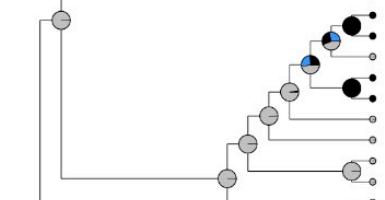
Sphaeropezia diffindens
Sphaeropezia ochrolechia Sphaeropezia ochrolechiae Sphaeropezia cassiopes Sphaeropezia capreae 2 Sphaeropezia capreae 1 Sphaeropezia shangrilaensis - Sphaeropezia leucocheila Cryptodiscus pini 2 Cryptodiscus pini 3 Cryptodiscus pini 1 Cryptodiscus galaninae Cryptodiscus pallidus Cryptodiscus pallidus 2 Cryptodiscus gloeocapsa Cryptodiscus cladoniicola 1 Cryptodiscus epicladonia Cryptodiscus tabularum 1 Cryptodiscus tabularum 2 Cryptodiscus tabularum 3 Cryptodiscus muriformis 2 Cryptodiscus muriformis 1 Cryptodiscus foveolaris 2 Cryptodiscus foveolaris 1 Ingvariella bispora 3 Ingvariella bispora 1 Ingvariella bispora 2 Xyloschistes platytropa Geisleria sychnogonoides 3 Geisleria sychnogonoides Absconditella sphagnorum Cyanodermella viridul Cyanodermella asteris
Cyanodermella banksiae Cyanodermella oleoligni Phaeographis spondaica Trichothelium epiphyllu
Porina nucula

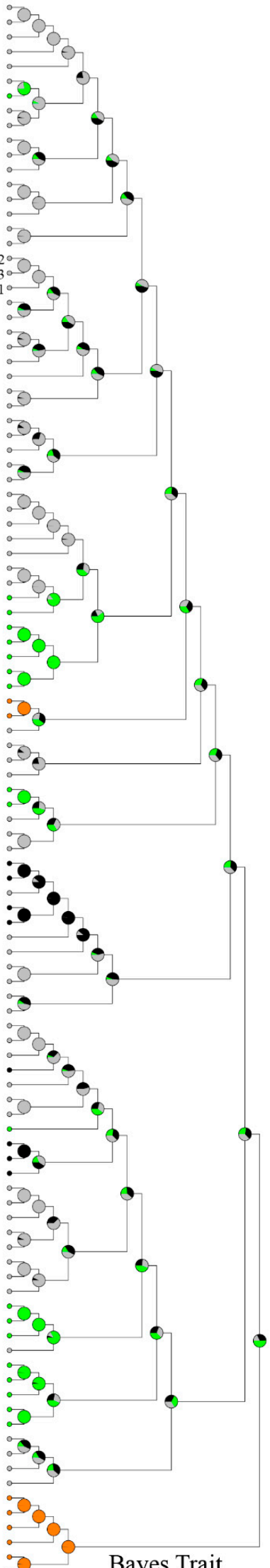

BBM (MCMC)

Bayes Trait

Figure 3. Ancestral character state analysis of Stictidaceae using Bayesian Binary MCMC and Bayes Traits. Color symbols indicate: green $=$ chlorococcoid , orange $=$ trentepohlioid , gray $=$ non-lichenized saprotrophic, black = lichenicolous. 
Bayesian binary MCMC and Bayes traits analyses give different results regarding the ancestral character analysis. Stictidaceae as a whole was recovered as basally nonlichenized in the Bayesian Binary MCMC tree, suggesting multiple secondary lichenizations of the lichenized lineages within the family. The results for Bayes traits were ambiguous for the basal nodes, not allowing any conclusions about the directionality of lichenization and delichenization.

\subsection{Taxonomy} 68 [51]

Ostropales Nannf., Nova Acta Regiae Societatis Scientiarum Upsaliensis, Ser. 4, 8 (2):

Kraichak et al. [13] and Lücking [30] reduced Ostropales sensu stricto to the single family Stictidaceae, which is a classification that is followed here.

Stictidaceae Fr., Summa vegetabilium Scandinaviae 2: 345, 372 [52]

Syn.: Ostropaceae Rehm (as 'Ostropeae'), Rabenh. Krypt.-Fl., Edn 2 (Leipzig) 1.3 (lief. 30): 185 (1888) (1896)

Type: Stictis Pers., Observationes mycologicae 2: 73 (1800)

Stictidaceae comprises both lichenized and non-lichenized fungi [1,3,18,19,28,31-33,5361]. Based on Fries's classification [62], Stictis (including subgen. Propolis and subgen. Xylographa) and Cryptomyces were tentatively included in Stictidaceae. After 1830, the improvement of microscopic-based studies lead to more detailed insight into hymenial configuration. Corda [63] divided immersed, non-stromatic discomycetes into four genera in which he included Stictis with unicellular, colorless, and ovoid spores. However, species and generic-level delineation remained uncertain from 1832 to 1932. Fries [52] again assigned Cryptomyces, Propolis, Xylographa, Naevia, and Propolis to Stictidaceae, ignoring the microscopic classification by Corda. After the inclusion of many genera, Ostropales was erected by Nannfeldt [51] with a single family Ostropaceae. Later, this family was synonymized under Stictidaceae, with the type genus Stictis [33,53].

The classification of the family Stictidaceae has changed over time $[1,14,15,23,33,52$, 53,62-66]. Its detailed taxonomy was first studied by Sherwood, focusing on excipular structure, ascospore type, and biology [33,53]. Stictidaceae was traditionally classified as saprotrophic lineage in Ostropales [67]. Gilenstam [68] initially included Conotrema as a lichenized genus in the family, whereas currently various lichenized lineages are distinguished, including Absconditella, Geisleria, Ingvariella, and Trinathotrema. Among these, Trinathotrema is the only genus associated with a trentepohlioid photobiont, while other lichenized genera are associated with chlorococcoid photobionts [67,69-71]. Winka et al. [72] accepted both lichenized and non-lichenized fungi within this family based on combined multi-gene analysis.

Presently, Stictidaceae comprises 33 genera: Absconditella, Acarosporina, Biostictis, Carestiella, Conotremopsis, Cryptodiscus, Cyanodermella, Delpontia, Dendroseptoria, Eriospora, Fitzroyomyces, Geisleria, Glomerobolus, Hormodochis, Ingvariella, Karstenia, Lillicoa, Nanostictis, Neostictis, Neofitzroyomyces, Ostropa, Ostropomyces, Phacidiella, Propoliopsis, Robergea, Schizoxylon, Sphaeropezia, Stictis, Stictophacidium, Thelopsis, Topelia, Trinathotrema, and Xyloschistes $[1,14,15,64]$. Generic classification in the family is challenging, given that the convergent evolution of ascoma types is frequent [19] and both apothecoid and perithecoid ascomata have evolved several times in separate lineages [33,73]. However, our updated phylogeny suggests that the only problematic genus at the moment is Stictis sensu lato.

Ostropomyces Thiyagaraja, Lücking, Ertz and K.D. Hyde, gen. nov. Index Fungorum number: IF 556555; Faces of Fungi number: FoF 09511 Etymology: name refers to the characteristics similar to Ostropa.

Type species: Ostropomyces pruinosellus Thiyagaraja, Lücking, Ertz and K.D. Hyde sp. nov.

Saprobic on bark, thallus whitish, pruinose. Sexual morph: Ascomata perithecial, solitary, immersed to erumpent. Ostiole distinct. Exciple with clear border between outer and inner layer. Hamathecium comprising filamentous paraphyses. Paraphyses septate, branched, hyaline, filamentous. Asci cylindrical, bitunicate. Ascospores overlapping unis- 
eriate, hyaline, transversely multi-septate, cells almost of equal size, deeply constricted at the septa of each cell, easily breaking into small septate part-spores. Asexual morph: Pycnidia erumpent, globose. Pycnidial wall in transverse section shows two distinct layers. Outer layer hyaline, densely packed. Inner layer hyaline, loosely packed, cells elongate in pycnidial neck. Conidiophores lining inside and outside of pycnidia wall. Conidiogenous cells hyaline. Conidia similar in shape to ascospore, filiform, aseptate, hyaline, and guttulate at maturity.

Notes: Ostropomyces is introduced to accommodate two newly discovered species, Ostropomyces pruinosellus and Ostropomyces thailandicus, which are collected from tropical forests in Northern Thailand. The new genus is related to Ostropa, but both emerge on long stem branches in our phylogenetic analyses (Figure 2). Ostropomyces differs from Ostropa in the presence of perithecial ascomata, presence of periphysoids, which are present in the inner face of the wall, in the lack of an apical cap in the ascus and four-spored asci. In contrast, Ostropa forms orbicular ascomata opening by a transverse slit, periphysoids in the above part, a prominent apical cap in the ascus, and eight-spored or polysporous asci [33]. The new genus formed a distinct clade with high bootstrap support in the multi-gene phylogenetic analyses, whereas its relationship to Ostropa was also strongly supported $(84 \%)$.

The morphological characteristics would initially suggest that $O$. thailandicus may represent an asexual state of $O$. pruinosellus. However, both lineages formed comparatively long branches in the phylogenetic analysis, indicating that they represent two closely related yet separate species - one known by its sexual morph and the other by its asexual state. Therefore, we introduce O. thailandicus and O. pruinosellus as new species in Ostropomyces. The taxa are characterized by immersed to erumpent fruiting bodies with pseudostromatic masses, orbicular in cross-section, loosely packed hyphae, with numerous periphysoids, numerous, branched, and filiform true paraphyses, long-cylindrical asci without prominent apical cap, four-spored asci, ascospores filiform, colorless, and transversely multi-septate.

Ostropomyces pruinosellus Thiyagaraja, Lücking, Ertz and K.D. Hyde, sp. nov. (Figure 4).

Index Fungorum number: IF 556556; Faces of Fungi number: FoF 09512 Etymology: The name refers to the pruinose surface of the substrate where the fungus produces ascomata.

Holotype: MFLU 20-0538

Saprobic on unidentified dead stem. Surface of the substrate where the ascomata are formed brownish white, appearing pruinose. Prothallus absent. Sexual morph: Ascomata perithecial, 310-350 $\mu \mathrm{m}$ high, 340-500 $\mu \mathrm{m}$ wide $(\overline{\mathrm{x}}=330 \times 420 \mu \mathrm{m}, \mathrm{n}=5)$, immersed to erumpent, solitary, margin partly protruding beyond the surface layers of stem, not carbonized, color unchanged in $\mathrm{KOH}$, orbicular in cross-section, lined with numerous periphysoids. Exciple thickened, outer layer 10-45 $\mu \mathrm{m}$ thick, densely packed, darker than inner layer, inner layer 3-8 $\mu \mathrm{m}$ thick $(\overline{\mathrm{x}}=27.5 \times 5.5 \mu \mathrm{m}, \mathrm{n}=10)$, hyaline, of loosely packed hyphae, with numerous crystalline inclusions and periphysoids extended to the entire inner face of the wall in the 2/3 upper part of the ascomata. Hamathecium comprising paraphyses and asci. Paraphyses septate, branched, hyaline, $0.5-1.3 \mu \mathrm{m}$ thick, generally exceeding the length of asci. Asci 165-245 $\times 7-11 \mu \mathrm{m}(\overline{\mathrm{x}}=205 \times 9 \mu \mathrm{m}, \mathrm{n}=40)$, bitunicate, cylindrical, four-spored, apical wall thickened to 2.2-3.2 $\mu \mathrm{m}$. Ascospores 160-180 $\times 2-3 \mu \mathrm{m}$ $(\bar{x}=170 \times 2.5 \mu \mathrm{m}, \mathrm{n}=40)$, hyaline, transversely multi-septate, each cells almost of equal size, each locus $2-4 \mu \mathrm{m}$ long, deeply constricted at each septa, easily breaking apart into small, septate, part-spores. Asexual morph: Undetermined.

Spot reactions: Asci KI-, Ascospores KI-

Material examined: Thailand, Mueang Khong, Chiang Dao District, Chiang Mai, $\mathrm{N} 97^{\circ} 92^{\prime} 86^{\prime \prime}, \mathrm{E} 17^{\circ} 71^{\prime} 45^{\prime \prime}$, $558 \mathrm{~m}$ elevation, on unidentified dead stem, 16 February 2019, Vinodhini Thiyagaraja, S1DA (holotype: MFLU 20-0538). 

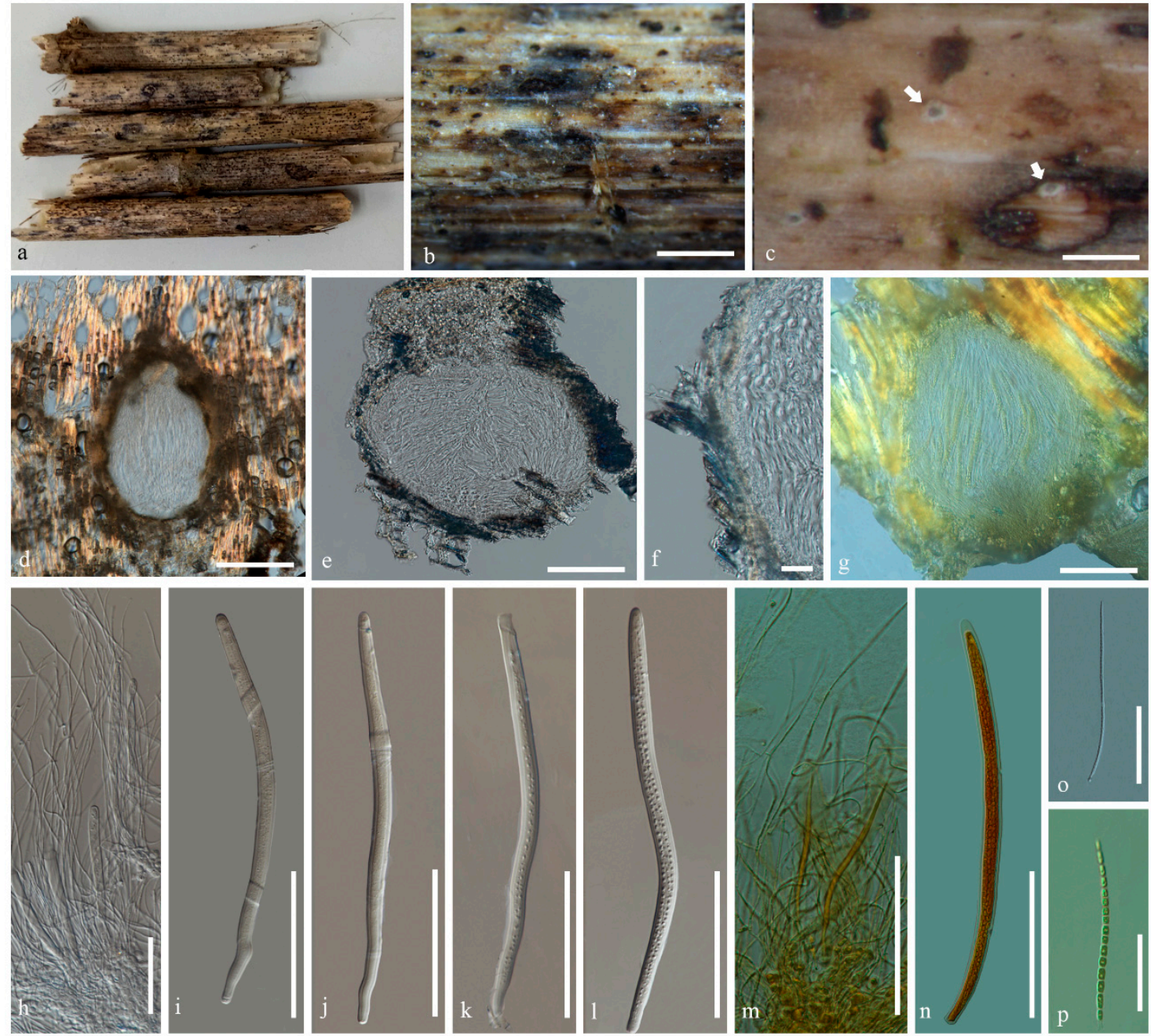

Figure 4. Ostropomyces pruinosellus (MFLU 20-0538). (a-c) Ascomata on substrate. (d,e) Vertical section through ascoma (in water). (f) Vertical section through exciple (in water). (g) Vertical section through ascoma (in KI). (h) Paraphyses (in water). (i-1) Asci (in water). (m) Paraphyses (in KI). (n) Asci (in KI). (o) Ascospores (in water). (p) Ascospores (in KI). Scale bars b, $\mathrm{c}=1000 \mu \mathrm{m}, \mathrm{d}, \mathrm{e}, \mathrm{g}-\mathrm{n}=100 \mu \mathrm{m}, \mathrm{f}=30 \mu \mathrm{m}, \mathrm{o}, \mathrm{p}=50 \mu \mathrm{m}$.

Notes: Ostropomyces pruinosellus is similar to species in Ostropa but differs in the characters listed in the genus discussion. Although the species is saprotrophic and not lichenized, the surface of the substrate where the ascomata emerges has a pruinose appearance, at first glance suggesting the presence of a thallus. However, the apparent thallus is absent. Initially, the ascomata were immersed and became erumpent at maturity.

Ostropomyces thailandicus Thiyagaraja, Lücking, Ertz and K.D. Hyde sp. nov.

Index Fungorum number: IF 556557; Faces of Fungi number: FoF 09513 Etymology: The name refers to the country where the type specimen of the new species was collected.

Holotype: MFLU 20-0539

Saprobic on dead stem. Area with pycnidia with a pruinose appearance on the surface. Prothallus absent. Sexual morph: Undetermined. Asexual morph: Pycnidia ca $100 \mu \mathrm{m}$ diam., globose, erumpent, darkening above. Pycnidial wall in transverse section composed of two distinct layers. Outer layer 19-27 $\mu \mathrm{m}$ wide, hyaline, densely packed, darker than inner layer. Inner layer hyaline, loosely packed, 11-23 $\mu \mathrm{m}$ wide. Conidiophores reduced to 9-15 $\mu \mathrm{m}$. Conidiogenous cells 9-15 $\mu \mathrm{m}$, cylindrical, hyaline, lining the inside and outside of the pycnidia wall. Conidia $8-13 \times 1-3 \mu \mathrm{m}(\overline{\mathrm{x}}=10.5 \times 2 \mu \mathrm{m}, \mathrm{n}=10)$, filiform, apical proliferation of the conidiogenous cell, aseptate, hyaline.

Spot reactions: Conidiophore KI-, Conidia KI- 
Material examined: Thailand, Mueang Khong, Chiang Dao District, Chiang Mai, $\mathrm{N} 97^{\circ} 92^{\prime} 86^{\prime \prime}, \mathrm{E} 17^{\circ} 71^{\prime} 45^{\prime \prime}, 558 \mathrm{~m}$ elevation, on unidentified dead stem, 16 February 2019, Vinodhini Thiyagaraja, S1D1T2 (holotype: MFLU 20-0539).

Notes: The new strain was collected from Thailand on the same material from which Ostropomyces pruinosellus was isolated (Figure 5). The species are delineated based on DNA sequence data as recommended by Jeewon and Hyde [74]. The phylogenetic tree supported O. pruinosellus and O. thailandicus as two distinct species, with more than $2 \%$ differences in LSU and ITS base pair comparisons. Ostropomyces thailandicus formed pycnidial conidiomata, reduced conidiophore into conidiogenous cells, hyaline, and filiform conidia similar to other asexual fungi recorded in Stictidaceae such as Acarosporina microspora, Cyanodermella oleoligni, Stictis radiata, and S. urceolata $[28,31,33,68,75]$.
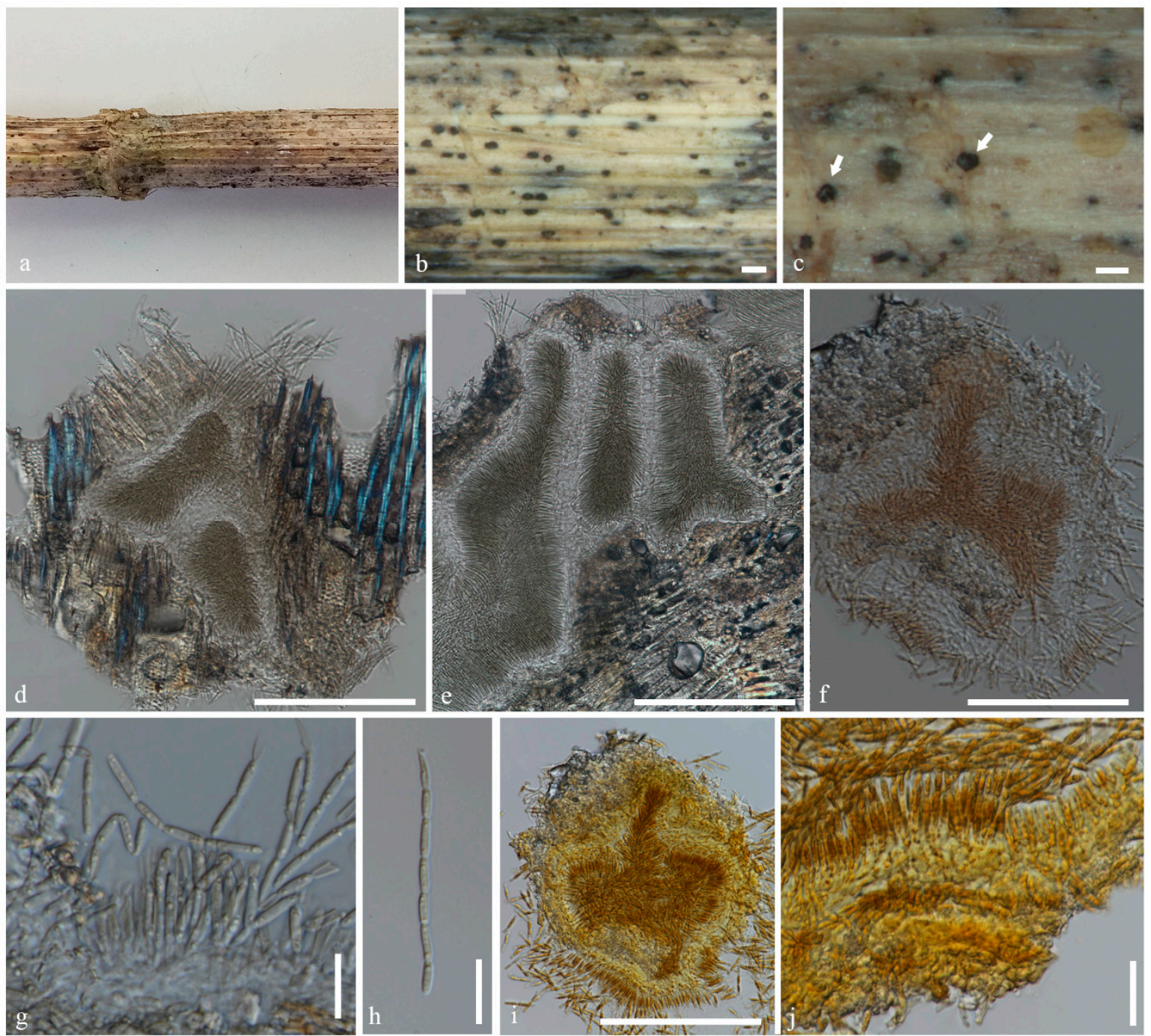

Figure 5. Ostropomyces thailandicus (MFLU 20-0539, holotype). (a-c) Pycnidium on substrate. (d,e) Vertical section through pycnidia (in water). (f), Vertical section through pycnidia (in $5 \% \mathrm{KOH}$ ). (g) Conidiophores (in water). (h) Conidia (in water). (i) Vertical section through pycnidia (in KI). (j) Conidiophores (in KI). Scale bars b, c =500 $\mu \mathrm{m}, \mathrm{d}-\mathrm{f}, \mathrm{i}=200 \mu \mathrm{m}, \mathrm{g}$, h, $\mathrm{j}=10 \mu \mathrm{m}$.

Sphaeropezia shangrilaensis Thiyagaraja, Lücking, Ertz and K.D. Hyde, sp. nov. (Figure 6) Index Fungorum number: IF 556558; Faces of Fungi number: FoF 09514 Etymology: Refers to the location in China (Shangri-La) where the type specimen was collected. 

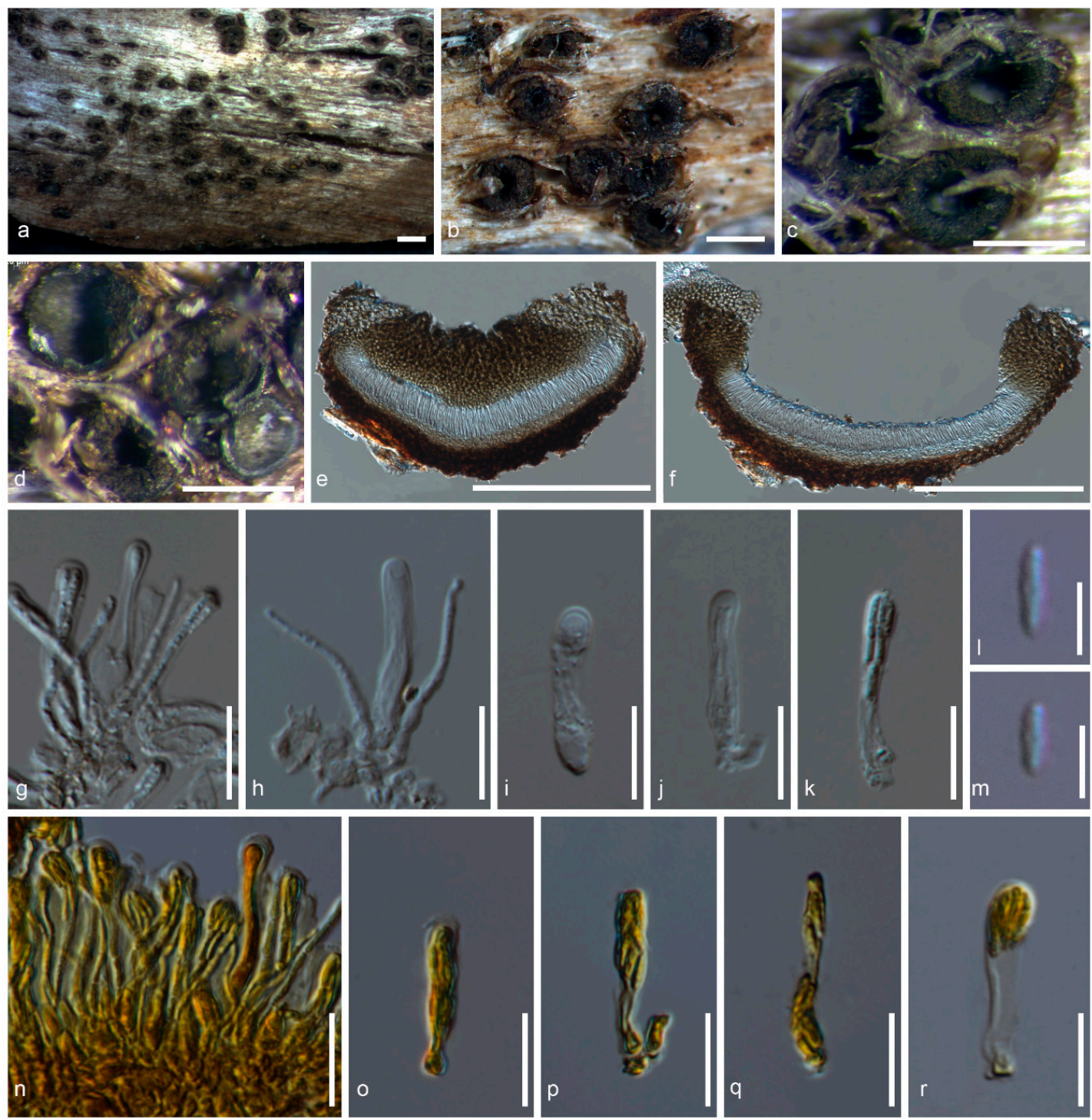

Figure 6. Sphaeropezia shangrilaensis (MFLU 20-0537). (a-d) Ascomata on substrate. (e,f) Vertical section through an ascoma (in water). (g) Paraphyses (in water). (h-k) Asci (in water). (1,m) Ascospores (in water). (n-r) Asci (in KI). Scale bars $\mathrm{a}=1000 \mu \mathrm{m}, \mathrm{b}-\mathrm{d}=500 \mu \mathrm{m}, \mathrm{e}, \mathrm{f}=200 \mu \mathrm{m}, \mathrm{g}-\mathrm{k}, \mathrm{n}-\mathrm{r}=10 \mu \mathrm{m}, \mathrm{l}, \mathrm{m}=5 \mu \mathrm{m}$.

\section{Holotype: MFLU 20-0537}

Saprobic on bark. Thallus unapparent, surface of the substrate where the ascomata are formed whitish gray, pruinose, crustose, epiphloedal. Prothallus absent. Photobiont not detected. Sexual morph: Ascomata apothecial, 345-450 $\mu \mathrm{m}$ diam., black, circular to ellipsoidal, adnate, margin 80-100 $\mu \mathrm{m}$, slightly erumpent from the thallus, in mature apothecia rolled inward leaving a distinct opening 270-285 $\mu \mathrm{m}$ diam., dark brown, carbonized. Exciple 16-38 $\mu \mathrm{m}$, distinct, dark brown at the base and both sides, light brown in the upper part, 57-87 $\mu \mathrm{m}$ thick. Hypothecium 11-21 $\mu \mathrm{m}$ thick, distinct, light brown. Hymenium $23-28 \mu \mathrm{m}$ thick, hyaline. Epihymenium 3-7 $\mu \mathrm{m}$ thick, hyaline. Paraphyses 1-2.4 $\mu \mathrm{m}$ wide, hyaline, densely arranged. Asci $21-24 \times 4-6 \mu \mathrm{m}(\overline{\mathrm{x}}=22.5 \times 5 \mu \mathrm{m}, \mathrm{n}=40)$, hyaline, clavate to obovoid, eight-spored but sometimes four-spored when immature, unitunicate, multiseriate, tip blunted, not narrowing towards the apex, tholus thickened, lacking an apical cap, with poorly developed stipe. Ascospores 4-6 $\times 0.7-1.0 \mu \mathrm{m}(\overline{\mathrm{x}}=5 \times 0.85 \mu \mathrm{m}, \mathrm{n}=40)$, hyaline, smooth-walled, fusoid to obovoid, (0-)1-septate. Asexual morph: Undetermined

Spot reactions: Ascomatal gel I-, KI-. Hymenium I-, KI-. Asci I-, KI-. Ascospores I-, KI- 


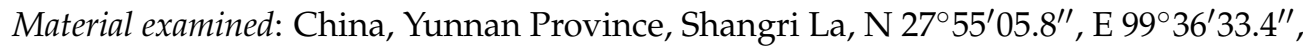
3964 m elevation, on unidentified dead bark, 14 September 2018, Vinodhini Thiyagaraja, D6S51 (holotype: MFLU 20-0537)

Notes: Sphaeropezia was resurrected by Baloch et al. [18] and comprises 22 species with S. alpina as the type [34]. Sphaeropezia was originally introduced by Saccardo [76] and associated with Odontotrema with the special adaptation to a foliicolous growth and was assigned to Odontotremataceae due to shared morphological characteristics [18]. However, Sphaeropezia was placed in Stictidaceae based on molecular data and some Bryodiscus species, which had been recorded as parasites on mosses, were also transferred to Sphaeropezia [18].

Species of this genus are characterized by dark-walled, deeply urceolate apothecia, mostly erumpent at maturity, living as saprobes on wood or herbaceous material, or as putative parasites of bryophytes or lichens. They are distributed mainly in northern temperate regions [18]. The new taxon was collected from the sub-tropical region of southwestern of Shangri la, China, which is one of the world's biodiversity hotspots [77]. Sphaeropezia shangrilaensis clustered together with S. leucocheila and formed a clade with S. capreae with high statistical support in the multi-gene phylogenetic analyses. The new taxon differs from other Sphaeropezia species in the larger pore opening in ascomata and the smaller asci (Figure 6; Table 2).

Specifically, Sphaeropezia shangrilaensis differs from S. capreae in the position of the ascomata (superficial vs. fully erumpent), the larger ascomatal pore opening (273-283 $\mu \mathrm{m}$ vs. $(60-) 100-150(-200)) \mu \mathrm{m}$, the smaller asci $(21-24 \times 4-5 \mu \mathrm{m}$ vs. $55-65 \times 8-10 \mu \mathrm{m})$, the shape of ascospores (bacilliform vs. fusoid to obvoid), and the number of ascospores per asci (4 to 8 vs. polyspored). Sphaeropezia shangrilaensis also differs from S. leucocheila in the shape of the ascomata (roundish vs. globose), the larger pore opening (273-283 $\mu \mathrm{m}$ vs. $80 \mu \mathrm{m})$, the smaller asci $(21-24 \times 4-5 \mu \mathrm{m}$ vs. $50-55 \times 6-8 \mu \mathrm{m})$, and the size of the ascospores $(4-6 \times 0.7-1.0 \mu \mathrm{m}$ vs. $8-11.5 \times 2-3 \mu \mathrm{m})$ [78]. Sphaeropezia shangrilaensis is only known from China while S. capreae and S. leucocheila were recorded from Sweden and New Zealand, respectively [18,78]. 
Table 2. Synopsis of recorded Sphaeropezia species.

\begin{tabular}{|c|c|c|c|c|c|c|c|c|c|c|}
\hline Species Name & $\begin{array}{l}\text { Position of } \\
\text { Ascoma }\end{array}$ & $\begin{array}{l}\text { Shape of } \\
\text { Ascoma }\end{array}$ & $\begin{array}{c}\text { Size of Ascoma } \\
(\mu \mathrm{m})\end{array}$ & $\begin{array}{c}\text { Size of Ascoma } \\
\text { Pore Opening }(\mu \mathrm{m})\end{array}$ & $\begin{array}{c}\text { Size of Asci } \\
(\mu \mathrm{m})\end{array}$ & Spore Size $(\mu \mathrm{m})$ & $\begin{array}{c}\text { Ascospore } \\
\text { Shape }\end{array}$ & $\begin{array}{c}\text { Number of } \\
\text { Septate }\end{array}$ & $\begin{array}{c}\text { Known } \\
\text { Distribution }\end{array}$ & Reference \\
\hline $\begin{array}{l}\text { Sphaeropezia } \\
\text { santessonii }\end{array}$ & $\begin{array}{l}\text { Immersed, } \\
\text { partly erumpent, } \\
\text { finally sessile }\end{array}$ & - & $\begin{array}{c}(225-) 280-380 \\
(-440)\end{array}$ & $(20-) 55-125(-190)$ & $\begin{array}{c}40-50(-55) \times \\
8-13\end{array}$ & $\begin{array}{c}(12 \cdot 5-) 15 \cdot 4-20 \cdot 4 \\
(-23 \cdot 5) \times(3-) \\
3 \cdot 6-4 \cdot 6(-5)\end{array}$ & $\begin{array}{l}\text { Fusiform, often } \\
\text { asymmetrical }\end{array}$ & $\begin{array}{c}\text { trans-septate } \\
(3-) 6-8 \\
(-9) \text { to } \\
\text { submuriform }\end{array}$ & $\begin{array}{c}\text { Russian Arctic, } \\
\text { Iceland and Peru, } \\
\text { widespread and } \\
\text { common in Arctic } \\
\text { regions }\end{array}$ & [79] \\
\hline S. bryoriae & Superficial & $\begin{array}{l}\text { Roundish to } \\
\text { subspherical }\end{array}$ & $\begin{array}{c}(275-) 310-410 \\
(-440)\end{array}$ & $(0-)$ 10-70 (-120) & $40-60 \times 5-6$ & $\begin{array}{c}(7 \cdot 4-) 7 \cdot 6-8 \cdot 8 \\
(-9 \cdot 2) \times(2 \cdot 8-) 3 \\
1-3 \cdot 5(-4 \cdot 0)\end{array}$ & Ellipsoid & $\begin{array}{c}\text { 1-septate } \\
\text { (exceptionally } \\
\text { 2-septate) }\end{array}$ & USA (Washington) & [79] \\
\hline S. capreae & Fully erumpent & & $(280-)$ 350-450 & $(60-)$ 100-150 (-200) & $55-65 \times 8-10$ & $\begin{array}{c}(4-) 5-7(-8) \times \\
1-1.3(-1.5) \\
\end{array}$ & Bacilliform & - & Sweden & [18] \\
\hline S. leucocheila & Superficial & $\begin{array}{l}\text { Globose- } \\
\text { urceolate }\end{array}$ & Up to 300 & 80 & $50-55 \times 6-8$ & $8-11.5 \times 2-3$ & Oblong-elliptic & (0-) 1-septate & New Zealand & {$[78]$} \\
\hline S. lyckselensis & Erumpent & - & $\begin{array}{c}(175-) 250-350 \\
(-425)\end{array}$ & (25-) 40-75 (-125) & $35-60 \times 5-6.5$ & - & $\begin{array}{l}\text { Cylindrical } \\
\text { oblong }\end{array}$ & 3-septate & Northern Sweden & [18] \\
\hline S. melaneliae & Immersed & Roundish & $170-350$ & $0-20$ & $60-85 \times 6 \cdot 5-8.5$ & $\begin{array}{c}(12-) 12 \cdot 8-14 \cdot 4 \\
(-15 \cdot 5) \times(5 \cdot 4-) \\
5 \cdot 5-6 \cdot 1(-6 \cdot 3)\end{array}$ & Ellipsoid & $\begin{array}{c}\text { (1-)3-septate, } \\
\text { exceptionally } \\
\text { with one } \\
\text { longitudinal } \\
\text { septum }\end{array}$ & Sweden and Alaska & [79] \\
\hline S. mycoblasti & Erumpent & - & $\begin{array}{c}(140-) 190-280 \\
(-320)\end{array}$ & $(0-)$ 20-50 (-70) & $50-70 \times 7-9$ & $\begin{array}{c}(12.3-) 14.0-15.9 \\
(-17) \times(4.0-) \\
4.7-5.3(-5.7)\end{array}$ & $\begin{array}{l}\text { Ellipsoid to } \\
\text { narrowly } \\
\text { ellipsoid }\end{array}$ & $\begin{array}{c}\text { 3-septate, } \\
\text { (exceptionally } \\
\text { 4-septate) }\end{array}$ & $\begin{array}{l}\text { USA (Oregon) and } \\
\text { northern Sweden }\end{array}$ & {$[18,70]$} \\
\hline S. ochrolechiae & $\begin{array}{l}\text { Immersed and } \\
\text { become } \\
\text { erumpent }\end{array}$ & - & $\begin{array}{c}(180-) 230-330 \\
(-400)\end{array}$ & $(0-)$ 5-50 (-150) & $50-75 \times 9-14$ & $\begin{array}{c}(10 \cdot 8-) 12 \cdot 1-14 \cdot 4 \\
(-16 \cdot 0) \times(4 \cdot 3-) \\
4 \cdot 8-5 \cdot 5(-6)\end{array}$ & $\begin{array}{l}\text { Ellipsoid to } \\
\text { narrowly } \\
\text { ellipsoid }\end{array}$ & 3-septate & $\begin{array}{l}\text { Norway, Sweden } \\
\text { and the USA } \\
\text { (Alaska) }\end{array}$ & [79] \\
\hline S. pertusariae & $\begin{array}{l}\text { Immersed to } \\
\text { erumpent }\end{array}$ & - & $\begin{array}{c}(140-) \text { 170-260 } \\
(-310)\end{array}$ & $(20-)$ 40-110 (-150) & - & $\begin{array}{c}(11 \cdot 5-) 12 \cdot 5-15 \cdot 4 \\
(-16 \cdot 0) \times(4 \cdot 5-) \\
4 \cdot 7 \\
-5 \cdot 5(-6 \cdot 0)\end{array}$ & Ellipsoid & $1-3$-septate & $\begin{array}{l}\text { Great Britain } \\
\text { (Scotland) }\end{array}$ & [79] \\
\hline S. rhizocarpicola & $\begin{array}{l}\text { Immersed and } \\
\text { occasionally } \\
\text { erumpent }\end{array}$ & Roundish & $\begin{array}{c}(140-) \text { 155-245 } \\
(-300)\end{array}$ & $(30-)$ 30-60 (-70) & $50-70 \times 6 \cdot 5-13$ & $\begin{array}{c}(8 \cdot 0-) 9 \cdot 3-11 \cdot 1 \\
(-13 \cdot 5) \times(4 \cdot 5-) \\
4 \cdot 8-5 \cdot 6(-6 \cdot 5)\end{array}$ & - & (1-)3-septate & $\begin{array}{l}\text { Russia, Kola and } \\
\text { Peninsula }\end{array}$ & [79] \\
\hline S. santessonii & $\begin{array}{l}\text { Immersed, } \\
\text {-finally sessile } \\
\text { partly erumpent }\end{array}$ & - & $\begin{array}{c}(225-) \text { 280-380 } \\
(-440)\end{array}$ & $(20-)$ 55-125 (-190) & $\begin{array}{c}40-50(-55) \times \\
8-13\end{array}$ & $\begin{array}{c}(12 \cdot 5-) 15 \cdot 4-20 \cdot 4 \\
(-23 \cdot 5) \times(3-) 3 \\
6-4.6(-5)\end{array}$ & $\begin{array}{l}\text { Fusiform, often } \\
\text { asymmetrical }\end{array}$ & $\begin{array}{c}\text { Trans-septate } \\
(3-) \\
6-8 \\
(-9) \text { to } \\
\text { submuriform }\end{array}$ & $\begin{array}{l}\text { Widespread and } \\
\text { common in Arctic } \\
\text { regions }\end{array}$ & [79] \\
\hline
\end{tabular}


Table 2. Cont

\begin{tabular}{|c|c|c|c|c|c|c|c|c|c|c|}
\hline Species Name & $\begin{array}{l}\text { Position of } \\
\text { Ascoma }\end{array}$ & $\begin{array}{l}\text { Shape of } \\
\text { Ascoma }\end{array}$ & $\begin{array}{c}\text { Size of Ascoma } \\
(\mu \mathrm{m})\end{array}$ & $\begin{array}{c}\text { Size of Ascoma } \\
\text { Pore Opening }(\mu \mathrm{m})\end{array}$ & $\begin{array}{l}\text { Size of Asci } \\
(\mu \mathrm{m})\end{array}$ & Spore Size $(\mu \mathrm{m})$ & $\begin{array}{l}\text { Ascospore } \\
\text { Shape }\end{array}$ & $\begin{array}{l}\text { Number of } \\
\text { Septate }\end{array}$ & $\begin{array}{c}\text { Known } \\
\text { Distribution }\end{array}$ & Reference \\
\hline S. sipei & $\begin{array}{l}\text { Immersed, soon } \\
\text { erumpent }\end{array}$ & Sub-spherical & $\begin{array}{c}(350-) 360-480 \\
(-590)\end{array}$ & $(0-) 0-40(-105)$ & $55-65 \times 5-7$ & $\begin{array}{c}(11 \cdot 0-) 12 \cdot 2-13 \cdot 8 \\
(-14 \cdot 5) \times(4 \cdot 2-) \\
4 \cdot 5-5 \cdot 0(-5 \cdot 0)\end{array}$ & $\begin{array}{l}\text { Ellipsoid to } \\
\text { narrowly } \\
\text { ellipsoid }\end{array}$ & 3-septate & $\begin{array}{l}\text { USA (Oregon) and } \\
\text { Canada (British } \\
\text { Columbia) }\end{array}$ & [79] \\
\hline S. thamnoliae & $\begin{array}{l}\text { Immersed and } \\
\text { occasionally } \\
\text { sessile }\end{array}$ & $\begin{array}{l}\text { Roundish or } \\
\text { slightly } \\
\text { ellipsoid }\end{array}$ & $\begin{array}{c}(140-) 150-200 \\
(-290)\end{array}$ & $(0-)$ 20-60 (-85) & $30-45 \times 7-10$ & $\begin{array}{c}(9 \cdot 0-) 11 \cdot 0-14 \cdot 9 \\
(-18 \cdot 0) \times(2 \cdot 5-) \\
2 \cdot 5-3 \cdot 2(-3 \cdot 5)\end{array}$ & Fusiform & 1(-2)-septate & $\begin{array}{l}\text { Russian and } \\
\text { Swedish Arctic }\end{array}$ & [79] \\
\hline S. shangrilaensis & $\begin{array}{l}\text { Slightly } \\
\text { erumpent to } \\
\text { superficial }\end{array}$ & Roundish & $345-446$ & $273-283$ & $21-24 \times 4-5.5$ & $4-6 \times 0.7-1.0$ & $\begin{array}{l}\text { Fusoid to } \\
\text { obvoid }\end{array}$ & (0-) 1-septate & China & This study \\
\hline
\end{tabular}




\section{Discussion}

Molecular phylogenetic studies show that lichenization occurred several times independently in both Ascomycota and Basidiomycota [4-7,9,10]. Baloch et al. [19] concluded that independent saprotrophic lineages in Ostropales sensu lato resulted from multiple losses of lichenization. Lutzoni et al. [20] also stated that non-lichenized ostropalean species were derived from a lichenized ancestor. These findings have been confirmed by other recent studies [3,12], whereas others indicated a deeper loss of lichenization in the clade leading to Stictidaceae (Figure 3). The latter was in part also supported by our own analysis using Bayesian MCMC, suggesting multiple independent relichenization in the family, although the results from Bayes traits were ambiguous.

One lichenized genus that we did not include in our analysis of Stictidaceae was Topelia. The genus comprises eleven species, but molecular data are lacking except for the type species. In our multi-gene phylogenetic analyses, $T$. rosea formed a comparatively long branch, and its position relative to Stictidaceae was unstable. Stictidaceae is not the only family in Ostropales sensu lato showing close relationships of lichenized and saprotrophic lineages. The predominantly lichenized family Graphidaceae now also contains the saprotrophic species Furcaspora eucalypti and Rubikia evansii, apparently derived from a lichenized ancestor [80], and Agyrium in Pertusariales was also derived through delichenization [23]. Stictidaceae itself contains a wide diversity of lifestyles, which may vary not only at genus but also at the species level $[32,60,61]$. The biology of some taxa (e.g., Lillicoa palicprea and Delpontia) remains unresolved [33].

Apart from lichenized and saprotrophic lineages, the lichenicolous lifestyle appeared multiple times independently within Stictidaceae, as shown previously by Pino-Bodas et al. [81]. Aptroot [82] and Cáceres et al. [80] suggested that delichenization can lead to both lichenicolous and saprotrophic lifestyles, which is supported by our analysis. Aptroot [82] stated that relichenization is a rare case, often resulting in loosely associated lichenized forms. In this respect, optionally lichenized fungi such as Stictis mollis and Schizoxylon albescens are of interest, as they seem to be derived from non-lichenized ancestors. Several species of the saprotrophic genus Acarosporina also have been recorded as parasitic, causing cankers on Quercus and Fagus in eastern North America [33]. Cyanodermella comprises saprotrophic fungi [83], and at least one species, C. asteris, has been recorded as endophytic. Several species of the lichenized genus Absconditella have been recorded as pathogens on bryophytes [84]. Thus, lifestyle switches may drive evolution in Stictidaceae and potentially drive speciation, but this needs to be tested with a much broader sampling, especially of Stictis sensu lato. Lifestyle switches are overall unusually frequent in Ostropales sensu lato, showing the evolutionary plasticity of this enigmatic group [26,85-87]. More detailed molecular studies and increased taxon sampling are also needed to resolve generic and species-level limits in the family [31]. Surprisingly, our phylogeny suggests that the only problematic genus at this point is the polyphyletic Stictis sensu lato.

Supplementary Materials: The following are available online at https:/ /www.mdpi.com/2309-6 08X/7/2/105/s1. Figure S1. Best-scoring RAxML tree reconstructed based on analysis of a single dataset of mtSSU sequence data. Bootstrap support values for ML equal to or greater than $65 \%$ is defined above the nodes. Figure S2. Best-scoring RAxML tree reconstructed based on analysis of a single dataset of LSU sequence data. Bootstrap support values for ML equal to or greater than $65 \%$ is defined above the nodes. Figure S3. Best-scoring RAxML tree reconstructed based on analysis of a single dataset of ITS sequence data. Bootstrap support values for ML equal to or greater than $65 \%$ is defined above the nodes. Figure S4. Best-scoring RAxML tree reconstructed based on analysis of a single dataset of $\mathrm{mtSSU}$ sequence data. Bootstrap support values for BP equal to or greater than 0.90 is defined above the nodes. Figure S5. Best-scoring RAxML tree reconstructed based on analysis of a single dataset of LSU sequence data. Bootstrap support values for BP equal to or greater than 0.90 is defined above the nodes. Figure S6. Best-scoring RAxML tree reconstructed based on analysis of a single dataset of ITS sequence data. Bootstrap support values for BP equal to or greater than 0.90 is defined above the nodes. 
Author Contributions: Conceptualization, V.T., R.L., D.E. and K.D.H.; methodology, V.T., R.L., D.E., S.C.K., D.N.W., and K.D.H.; resources, K.D.H.; writing-original draft preparation, V.T., R.L. and D.E.; data acquisition, V.T.; writing-review and editing, R.L., D.E., S.C.K., D.N.W., S.L. and K.D.H.; supervision, R.L., D.E. and K.D.H.; funding acquisition, K.D.H. All authors have read and agreed to the published version of the manuscript.

Funding: The research was funded by Thailand Research Fund ("The future of specialist fungi in a changing climate: baseline data for generalist and specialist fungi associated with ants, Rhododendron species and Dracaena species DBG6080013" and "Impact of climate change on fungal diversity and biogeography in the Greater Mekong Sub-region RDG6130001").

Institutional Review Board Statement: Not applicable.

Informed Consent Statement: Not applicable.

Data Availability Statement: Not applicable.

Acknowledgments: Kevin D. Hyde thanks Chiang Mai University for the Award of Visiting Professor. We thank the Yunnan Provincial Human Resources and Social Security Bureau for a Yunnan Provincial Post-doctoral Grant to Fiona Worthy which financed the collecting expedition. We also thank Udeni Jayalal, Nalin Wijayawardene, and Banujan Kuhaneshwaran for their precious help during this research. S.C. Karunarathna would like to thank CAS President's International Fellowship Initiative (PIFI) under the following grant: 2018PC0006 and the National Science Foundation of China (NSFC, project code 31750110478). Dhanushka Wanasinghe would like to thank CAS President's International Fellowship Initiative (PIFI) for funding his postdoctoral research (number 2019PC0008), the National Science Foundation of China and the Chinese Academy of Sciences for financial support under the following grants: 41761144055, 41771063 and Y4ZK111B01. We also would like to thank Shaun Pennycook for helping in nomenclature.

Conflicts of Interest: The authors declare no conflict of interest.

\section{References}

1. Lücking, R.; Hodkinson, B.P.; Leavitt, S.D. The 2016 classification of lichenized fungi in the Ascomycota and BasidiomycotaApproaching one thousand genera. Bryologist 2017, 119, 361-416. [CrossRef]

2. Lücking, R.; Nelsen, M.P. Ediacarans, protolichens, and lichen-derived Penicillium: A critical reassessment of the evolution of lichenization in fungi. Transform. Paleobotany 2018, 551-590. [CrossRef]

3. Nelsen, M.P.; Lücking, R.; Boyce, C.K.; Lumbsch, H.T.; Ree, R.H. The macroevolutionary dynamics of symbiotic and phenotypic diversification in lichens. Proc. Natl. Acad. Sci. USA 2020, 117, 21495-21503. [CrossRef]

4. Gargas, A.; DePriest, P.T.; Grube, M.; Tehler, A. Multiple origins of lichen symbioses in fungi suggested by SSU rDNA phylogeny. Science 1995, 268, 1492-1495. [CrossRef]

5. Lawrey, J.D.; Lücking, R.; Sipman, H.J.; Chaves, J.L.; Redhead, S.A.; Bungartz, F.; Sikaroodi, M.; Gillevet, P.M. High concentration of basidiolichens in a single family of agaricoid mushrooms (Basidiomycota: Agaricales: Hygrophoraceae). Mycol. Res. 2009, 113, 1154-1171. [CrossRef] [PubMed]

6. Nelsen, M.; Lücking, R.; Grube, M.; Mbatchou, J.; Muggia, L.; Plata, E.R.; Lumbsch, H. Unravelling the phylogenetic relationships of lichenised fungi in Dothideomyceta. Stud. Mycol. 2009, 64, 135-144. [CrossRef]

7. Nelsen, M.P.; Lücking, R.; Mbatchou, J.S.; Andrew, C.J.; Spielmann, A.A.; Lumbsch, H.T. New insights into relationships of lichen-forming Dothideomycetes. Fungal Divers. 2011, 51, 155-162. [CrossRef]

8. Schoch, C.L.; Sung, G.-H.; López-Giráldez, F.; Townsend, J.P.; Miadlikowska, J.; Hofstetter, V.; Robbertse, B.; Matheny, P.B.; Kauff, F.; Wang, Z.; et al. The Ascomycota tree of life: A phylum-wide phylogeny clarifies the origin and evolution of fundamental reproductive and ecological traits. Syst. Biol. 2009, 58, 224-239. [CrossRef]

9. Prieto, M.; Wedin, M. Dating the diversification of the major lineages of Ascomycota (Fungi). PLoS ONE 2013, 8, e65576. [CrossRef]

10. Hodkinson, B.P.; Moncada, B.; Lücking, R. Lepidostromatales, a new order of lichenized fungi (Basidiomycota, Agaricomycetes), with two new genera, Ertzia and Sulzbacheromyces, and one new species, Lepidostroma winklerianum. Fungal Divers. 2014, 64, 165-179. [CrossRef]

11. Hawksworth, D.L. Lichenization: The origins of a fungal life-style. Recent Adv. Lichenol. 2015, 2, 1-10.

12. Lutzoni, F.; Nowak, M.D.; Alfaro, M.E.; Reeb, V.; Miadlikowska, J.; Krug, M.; Arnold, A.E.; Lewis, L.A.; Swofford, D.L.; Hibbett, D. Contemporaneous radiations of fungi and plants linked to symbiosis. Nat. Commun. 2018, 9, 1-11. [CrossRef] [PubMed]

13. Kraichak, E.; Huang, J.-P.; Nelsen, M.; Leavitt, S.D.; Lumbsch, H.T. A revised classification of orders and families in the two major subclasses of Lecanoromycetes (Ascomycota) based on a temporal approach. Bot. J. Linn. Soc. 2018, 188, 233-249. [CrossRef]

14. Wijayawardene, N.N.; Hyde, K.D.; Rajeshkumar, K.C.; Hawksworth, D.L.; Madrid, H.; Kirk, P.M.; Braun, U.; Singh, R.V.; Crous, P.W.; Kukwa, M.; et al. Notes for genera: Ascomycota. Fungal Divers. 2017, 86, 1-594. 
15. Wijayawardene, N.; Hyde, K.; Al-Ani, L.; Tedersoo, L.; Haelewaters, D.; Rajeshkumar, K.; Zhao, R.; Aptroot, A.; Leontyev, D.; Saxena, R.; et al. Outline of Fungi and fungus-like taxa. Mycosphere 2020, 11, 1060-1456. [CrossRef]

16. Voglmayr, H.; Fournier, J.; Jaklitsch, W. Two new classes of Ascomycota: Xylobotryomycetes and Candelariomycetes. Pers. Mol. Phylogeny Evol. Fungi 2019, 42, 36. [CrossRef]

17. Lücking, R.; Grube, M. Facultative parasitism and reproductive strategies in Chroodiscus (Ascomycota, Ostropales). Stapfia 2002, 80, 267-292.

18. Baloch, E.; Gilenstam, G.; Wedin, M. The relationships of Odontotrema (Odontotremataceae) and the resurrected Sphaeropezia (Stictidaceae)-New combinations and three new Sphaeropezia species. Mycologia 2013, 105, 384-397. [CrossRef]

19. Baloch, E.; Lücking, R.; Lumbsch, H.T.; Wedin, M. Major clades and phylogenetic relationships between lichenized and nonlichenized lineages in Ostropales (Ascomycota: Lecanoromycetes). Taxon 2010, 59, 1483-1494. [CrossRef]

20. Lutzoni, F.; Pagel, M.; Reeb, V. Major fungal lineages are derived from lichen symbiotic ancestors. Nature 2001, 411, 937-940. [CrossRef]

21. Kauff, F.; Lutzoni, F. Phylogeny of the Gyalectales and Ostropales (Ascomycota, Fungi): Among and within order relationships based on nuclear ribosomal RNA small and large subunits. Mol. Phylogenet. Evol. 2002, 25, 138-156. [CrossRef]

22. Lumbsch, H.T.; Schmitt, I.; Palice, Z.; Wiklund, E.; Ekman, S.; Wedin, M. Supraordinal phylogenetic relationships of Lecanoromycetes based on a Bayesian analysis of combined nuclear and mitochondrial sequences. Mol. Phylogenet. Evol. 2004, 31, 822-832. [CrossRef] [PubMed]

23. Lumbsch, H.T.; Schmitt, I.; Mangold, A.; Wedin, M. Ascus types are phylogenetically misleading in Trapeliaceae and Agyriaceae (Ostropomycetidae, Ascomycota). Mycol. Res. 2007, 111, 1133-1141. [CrossRef] [PubMed]

24. Wedin, M.; Doering, H.; Koenberg, K.; Gilenstam, G. Generic delimitations in the family Stictidaceae (Ostropales, Ascomycota): The Stictis-Conotrema problem. Lichenologist 2005, 37, 67-75. [CrossRef]

25. Miadlikowska, J.; Kauff, F.; Hofstetter, V.; Fraker, E.; Grube, M.; Hafellner, J.; Reeb, V.; Hodkinson, B.P.; Kukwa, M.; Lücking, R.; et al. New insights into classification and evolution of the Lecanoromycetes (Pezizomycotina, Ascomycota) from phylogenetic analyses of three ribosomal RNA-and two protein-coding genes. Mycologia 2006, 98, 1088-1103. [CrossRef] [PubMed]

26. Miadlikowska, J.; Kauff, F.; Högnabba, F.; Oliver, J.C.; Molnár, K.; Fraker, E.; Gaya, E.; Hafellner, J.; Hofstetter, V.; Gueidan, C.; et al. A multigene phylogenetic synthesis for the class Lecanoromycetes (Ascomycota): 1307 fungi representing 1139 infrageneric taxa, 317 genera and 66 families. Mol. Phylogenet. Evol. 2014, 79, 132-168. [CrossRef] [PubMed]

27. Yang, C.; Baral, H.-O.; Xu, X.; Liu, Y. Parakarstenia phyllostachydis, a new genus and species of non-lichenized Odontotremataceae (Ostropales, Ascomycota). Mycol. Prog. 2019, 18, 833-845. [CrossRef]

28. Baloch, E.; Gilenstam, G.; Wedin, M. Phylogeny and classification of Cryptodiscus, with a taxonomic synopsis of the Swedish species. Fungal Divers. 2009, 38, 51-68.

29. Tehler, A.; Wedin, M. Systematics of lichenised fungi. Lichen Biol. 2008, 336-352. [CrossRef]

30. Lücking, R. Stop the abuse of time! Strict temporal banding is not the future of rank-based classifications in fungi (including lichens) and other organisms. Crit. Rev. Plant Sci. 2019, 38, 199-253. [CrossRef]

31. Fernández-Brime, S.; Olariaga, I.; Baral, H.-O.; Friebes, G.; Jaklitsch, W.; Senn-Irlet, B.; Wedin, M. Cryptodiscus muriformis and Schizoxylon gilenstamii, two new species of Stictidaceae (Ascomycota). Mycol. Prog. 2018, 17, 295-305. [CrossRef]

32. Wedin, M.; Döring, H.; Gilenstam, G. Saprotrophy and lichenization as options for the same fungal species on different substrata: Environmental plasticity and fungal lifestyles in the Stictis-Conotrema complex. New Phytol. 2004, 164, 459-465. [CrossRef]

33. Sherwood, M.A. The ostropalean fungi. Mycotaxon 1977, 5, 1-277.

34. Index Fungorum. Available online: http://www.indexfungorum.org/Names/Names.asp (accessed on 15 December 2020).

35. Jayasiri, S.; Hyde, K.; Ariyawansa, H.; Bhat, J.; Buyck, B.; Cai, L.; Dai, Y.; Abd-Elsalam, K.; Ertz, D.; Hidayat, I.; et al. The faces of fungi database: Fungal names linked with morphology, molecular and human attributes. Fungal Divers. 2015, 74, 3-18. [CrossRef]

36. Wanasinghe, D.N.; Phukhamsakda, C.; Hyde, K.D.; Jeewon, R.; Lee, H.B.; Jones, E.G.; Tibpromma, S.; Tennakoon, D.S.; Dissanayake, A.J.; Jayasiri, S.C.; et al. Fungal diversity notes 709-839: Taxonomic and phylogenetic contributions to fungal taxa with an emphasis on fungi on Rosaceae. Fungal Divers. 2018, 89, 1-236. [CrossRef]

37. Zoller, S.; Scheidegger, C.; Sperisen, C. PCR primers for the amplification of mitochondrial small subunit ribosomal DNA of lichen-forming ascomycetes. Lichenologist 1999, 31, 511-516. [CrossRef]

38. Vilgalys, R.; Hester, M. Rapid genetic identification and mapping of enzymatically amplified ribosomal DNA from several Cryptococcus species. J. Bacteriol. 1990, 172, 4238-4246. [CrossRef]

39. White, T.J.; Bruns, T.; Lee, S.; Taylor, J. Amplification and direct sequencing of fungal ribosomal RNA genes for phylogenetics. PCR Protoc. Guide Methods Appl. 1990, 18, 315-322.

40. National Center for Biotechnology Information. Available online: https://www.ncbi.nlm.nih.gov/nuccore/?term= (accessed on 15 December 2020).

41. Katoh, K.; Standley, D.M. MAFFT multiple sequence alignment software version 7: Improvements in performance and usability. Mol. Biol. Evol. 2013, 30, 772-780. [CrossRef]

42. Hall, T.A. BioEdit: A User-Friendly Biological Sequence Alignment Editor and Analysis Program for Windows 95/98/NT, Nucleic Acids Symposium Series; Information Retrieval Ltd.: London, UK, 1999; pp. 95-98.

43. Daniel, G.-P.; Daniel, G.-B.; Reboiro-Jato, M.; Fdez-Riverola, F.; Posada, D. ALTER: Program-oriented conversion of DNA and protein alignments. Nucleic Acids Res. 2010, 38, W14-W18. 
44. Nylander, J. MrModeltest (Version 2.2); Evolutionary Biology Centre, Uppsala University: Uppsala, Sweden, 2004.

45. Miller, M.; Pfeiffer, W.; Schwartz, T. Creating the CIPRES Science Gateway for Inference of Large Phylogenetic Trees; Gateway Computing Environments Workshop (GCE): New Orleans, LA, USA, 2010.

46. Huelsenbeck, J.P.; Ronquist, F. MRBAYES: Bayesian inference of phylogenetic trees. Bioinformatics 2001, 17, 754-755. [CrossRef] [PubMed]

47. Rambaut, A. FigTree. Version 1.4.2; University of Edinburgh: Edinburgh, UK, 2014.

48. Joy, J.B.; Liang, R.H.; McCloskey, R.M.; Nguyen, T.; Poon, A.F. Ancestral reconstruction. PLoS Comput. Biol. 2016, 12, e1004763. [CrossRef] [PubMed]

49. Yu, Y.; Blair, C.; He, X. RASP 4: Ancestral state reconstruction tool for multiple genes and characters. Mol. Biol. Evol. 2020, 37, 604-606. [CrossRef] [PubMed]

50. Yu, Y.; Harris, A.J.; Blair, C.; He, X. RASP (Reconstruct Ancestral State in Phylogenies): A tool for historical biogeography. Mol. Phylogenet. Evol. 2015, 87, 46-49. [CrossRef]

51. Nannfeldt, J.A. Studien uber die Morphologie und Systematik der nicht-lichenisierten inoperculaten Discomyceten. Nova Acta Regiae Soc. Sci. Upsal. Ser. IV 1932, 8, 1-368.

52. Fries, E. Systema Mycologicum. Gryphiswaldiae 1849, 2, 1-275.

53. Sherwood, M.A. The ostropalean fungi: Schizoxylon, with notes on Stictis, Acarosporina, Cocropezia, and Carestiella. Mycotaxon 1977, 6, 215-260.

54. Phukhamsakda, C.; McKenzie, E.H.; Phillips, A.J.; Jones, E.G.; Bhat, D.J.; Stadler, M.; Bhunjun, C.S.; Wanasinghe, D.N.; Thongbai, B.; Camporesi, E.; et al. Microfungi associated with Clematis (Ranunculaceae) with an integrated approach to delimiting species boundaries. Fungal Divers. 2020, 102, 1-203. [CrossRef]

55. Ekanayaka, A.; Ariyawansa, H.; Hyde, K.; Jones, E.; Daranagama, D.; Phillips, A.; Hongsanan, S.; Jayasiri, S.; Zhao, Q. DISCOMYCETES: The apothecial representatives of the phylum Ascomycota. Fungal Divers. 2017, 87, 237-298. [CrossRef]

56. Ekanayaka, A.; Hyde, K.; Jones, E.; Zhao, Q.; Bulgakov, T. New and known discolichens from Asia and eastern Europe. Asian J. Mycol. 2019, 2, 48-86. [CrossRef]

57. Bernardin, J.R. A Morphological and Molecular Reassessment of Robergea albicedrae (Ascomycota). Master's Thesis, Texas State University, San Marcos, TX, USA, 2019.

58. Guderley, R.; Lumbsch, H.T.; Feige, G.B. Ingvariella, a new genus in the Thelotremataceae (lichenized Ascomycotina). Nova Hedwig. 1997, 147-154. [CrossRef]

59. Hayova, V.P. Some new and rare records of ascomycetes in Ukraine. Ukr. Bot. J. 2005, 62, 70-77.

60. Konoreva, L.A.; Chesnokov, S.V.; Davydov, E.A. Stictis and Schizoxylon (Stictidaceae, Ostropales) in Russia. Herzogia 2016, 29, 706-711. [CrossRef]

61. Popov, E.S.; Chesnokov, S.V.; Konoreva, L.A.; Ezhkin, A.K.; Stepanchikova, I.S.; Kuznetsova, E.S.; Himelbrant, D.E.; Galanina, I.A.; Tchabanenko, S.I. Stictis sl (Ostropales, Ascomycota) in the Russian Far East. Bot. Pac. J. Plant Sci. Conserv. 2020, 9, 1-8.

62. Fries, E. EM 1821-1832. Syst. Mycol. 1821, 3.

63. Corda, A. CJ. 1837. Icon. Fung. 1838, 1, 12.

64. Crous, P.; Wingfield, M.; Schumacher, R.; Akulov, A.; Bulgakov, T.; Carnegie, A.; Jurjević, Ž.; Decock, C.; Denman, S.; Lombard, L.; et al. New and interesting fungi. 3. Fungal Syst. Evol. 2020, 6, 157. [CrossRef]

65. Crous, P.W.; Wingfield, M.J.; Burgess, T.I.; Carnegie, A.J.; Hardy, G.S.J.; Smith, D.; Summerell, B.A.; Cano-Lira, J.F.; Guarro, J.; Houbraken, J.; et al. Fungal Planet description sheets: 625-715. Pers. Mol. Phylogeny Evol. Fungi 2017, 39, 270. [CrossRef]

66. Crous, P.W.; Wingfield, M.J.; Schumacher, R.; Summerell, B.A.; Giraldo, A.; Gené, J.; Guarro, J.; Wanasinghe, D.; Hyde, K.D.; Camporesi, E.; et al. Fungal Planet description sheets: 281-319. Pers. Mol. Phylogeny Evol. Fungi 2014, 33, 212. [CrossRef]

67. Fernández-Brime, S.; Llimona, X.; Molnar, K.; Stenroos, S.; Hognabba, F.; Bjork, C.; Lutzoni, F.; Gaya, E. Expansion of the Stictidaceae by the addition of the saxicolous lichen-forming genus Ingvariella. Mycologia 2011, 103, 755-763. [CrossRef]

68. Gilenstam, G. Studies in the lichen genus Conotrema. Ark. Bot. 1974, 7, 149-179.

69. Aptroot, A.; de Oliveira Mendonça, C.; Ferraro, L.I.; da Silva Caceres, M.E. A world key to species of the genera Topelia and Thelopsis (Stictidaceae), with the description of three new species from Brazil and Argentina. Lichenologist 2014, 46, 801. [CrossRef]

70. Bely, P. Absconditella lignicola (Stictidaceae)-lichen species new to Belarus. Botanica 2012, 18, 164-165. [CrossRef]

71. Lücking, R.; Rivas Plata, E.; Mangold, A.; Sipman, H.; Aptroot, A.; Miranda González, R.; Kalb, K.; Chaves, J.; Ventura, N.; Esmeralda Esquivel, R. Natural history of Nash's Pore Lichens, Trinathotrema (Ascomycota: Lecanoromycetes: Ostropales: Stictidaceae). Bibl. Lichenol. 2011, 106, 183-206.

72. Winka, K.; Ahlberg, C.; Eriksson, O.E. Are there lichenized Ostropales? Lichenologist 1998, 30, 455-462. [CrossRef]

73. James, T.Y.; Kauff, F.; Schoch, C.L.; Matheny, P.B.; Hofstetter, V.; Cox, C.J.; Celio, G.; Gueidan, C.; Fraker, E.; Miadlikowska, J. Reconstructing the early evolution of Fungi using a six-gene phylogeny. Nature 2006, 443, 818-822. [CrossRef]

74. Jeewon, R.; Hyde, K. Establishing species boundaries and new taxa among fungi: Recommendations to resolve taxonomic ambiguities. Mycosphere 2016, 7, 1669-1677. [CrossRef]

75. Van Nieuwenhuijzen, E.; Miadlikowska, J.; Houbraken, J.A.; Adan, O.C.; Lutzoni, F.; Samson, R. Wood staining fungi revealed taxonomic novelties in Pezizomycotina: New order Superstratomycetales and new species Cyanodermella oleoligni. Stud. Mycol. 2016, 85, 107-124. [CrossRef]

76. Saccardo, P.A. Conspectus generum Discomycetum hucuscue cognitorum. Bot. Cent. 1884, 18, 247-256. 
77. Zhu, H. Biogeography of Shangri-la flora in southwestern China. Phytotaxa 2015, 203, 231-244.

78. Johnston, P.; Park, D.; Renner, M. Sphaeropezia leucocheila sp. nov. (Stictidaceae): A liverwort pathogen from New Zealand. Phytotaxa 2019, 409, 222-226. [CrossRef]

79. Da Silva Cáceres, M.E.; Lücking, R.; Schumm, F.; Aptroot, A. A lichenized family yields another renegade lineage: Papilionovela albothallina is the first non-lichenized, saprobic member of Graphidaceae subfam. Graphidoideae. Bryologist 2020, 123, 144-154. [CrossRef]

80. Pino-Bodas, R.; Zhurbenko, M.; Stenroos, S. Phylogenetic placement within Lecanoromycetes of lichenicolous fungi associated with Cladonia and some other genera. Pers. Mol. Phylogeny Evol. Fungi 2017, 39, 91. [CrossRef] [PubMed]

81. Aptroot, A. Aspects of the integration of the taxonomy of lichenized and non-lichenized pyrenocarpous ascomycetes. Lichenologist 1998, 30, 501-514. [CrossRef]

82. Jahn, L.; Schafhauser, T.; Pan, S.; Weber, T.; Wohlleben, W.; Fewer, D.P.; Sivonen, K.; Flor, L.; van Pée, K.H.; Caradec, T. Cyanodermella asteris sp. nov. (Ostropales) from the inflorescence axis of Aster tataricus. Mycotaxon 2017, 132, 107-123. [CrossRef]

83. Stenroos, S.; Laukka, T.; Huhtinen, S.; Döbbeler, P.; Myllys, L.; Syrjänen, K.; Hyvönen, J. Multiple origins of symbioses between ascomycetes and bryophytes suggested by a five-gene phylogeny. Cladistics 2010, 26, 281-300. [CrossRef]

84. Lücking, R.; Tehler, A.; Bungartz, F.; Rivas Plata, E.; Lumbsch, H.T. Journey from the West: Did tropical Graphidaceae (lichenized Ascomycota: Ostropales) evolve from a saxicolous ancestor along the American Pacific coast? Am. J. Bot. 2013, 100, 844-856. [CrossRef]

85. Mangold, A.; Martín, M.P.; Lücking, R.; Thorsten Lumbsch, H. Molecular phylogeny suggests synonymy of Thelotremataceae within Graphidaceae (Ascomycota: Ostropales). Taxon 2008, 57, 476-486.

86. Parnmen, S.; Cáceres, M.E.; Lücking, R.; Lumbsch, H.T. Myriochapsa and Nitidochapsa, two new genera in Graphidaceae (Ascomycota: Ostropales) for chroodiscoid species in the Ocellularia clade. Bryologyst 2013, 116, 127-133. [CrossRef]

87. Diederich, P.; Zhurbenko, M.; Etayo, J. The lichenicolous species of Odontotrema (syn. Lethariicola) (Ascomycota, Ostropales). Lichenologist 2002, 34, 479-501. [CrossRef] 